Article

\title{
Investigation of Mechanical and Magnetic Properties of Co-Based Amorphous Powders Obtained by Atomization
}

\author{
Anna Kuś ${ }^{1, *(1)}$, Wirginia Pilarczyk ${ }^{2}\left(\mathbb{D}\right.$, Aleksandra Małachowska ${ }^{1}$, Andrzej Ambroziak ${ }^{1}$ and Piotr Gębara $^{3}(\mathbb{D}$ \\ 1 Faculty of Mechanical Enginerging, Wrocław Universtity of Science and Technology, Wyb. Wyspiańskiego 27, \\ 50-370 Wrocław, Poland; aleksandra.malachowska@pwr.edu.pl (A.M.); andrzej.ambroziak@pwr.edu.pl (A.A.) \\ 2 Faculty of Mechanical Engineering, Silesian University of Technology, ul. Akademicka 2A, \\ 44-100 Gliwice, Poland; wirginia.pilarczyk@polsl.pl \\ 3 Department of Physics, Częstochowa Universtity of Technology, Armii Krajowej 19, \\ 42-200 Częstochowa, Poland; piotr.gebara@pcz.pl \\ * Correspondence: anna.kus@pwr.edu.pl
}

check for

updates

Citation: Kuś, A.; Pilarczyk, W.; Małachowska, A.; Ambroziak, A.; Gębara, P. Investigation of

Mechanical and Magnetic Properties of Co-Based Amorphous Powders Obtained by Atomization. Materials 2021, 14, 7357. https://doi.org/ $10.3390 /$ ma14237357

Academic Editors: Baoan Sun and Chenchen Yuan

Received: 5 October 2021

Accepted: 22 November 2021

Published: 30 November 2021

Publisher's Note: MDPI stays neutral with regard to jurisdictional claims in published maps and institutional affiliations.

Copyright: (c) 2021 by the authors. Licensee MDPI, Basel, Switzerland. This article is an open access article distributed under the terms and conditions of the Creative Commons Attribution (CC BY) license (https:/ / creativecommons.org/licenses/by/ $4.0 /)$.

\begin{abstract}
Properties of Co-based alloys with high Glass Forming Ability (GFA) in the form of powder are still not widely known. However, powders of high GFA alloys are often used for the development of bulk metallic glasses by additive manufacturing. In this work $\mathrm{Co}_{47.6} \mathrm{~B}_{21.9} \mathrm{Fe}_{20.4} \mathrm{Si}_{5.1} \mathrm{Nb}_{5} \%$ at. and $\mathrm{Co}_{42} \mathrm{~B}_{26.5} \mathrm{Fe}_{20} \mathrm{Ta}_{5.5} \mathrm{Si}_{5} \mathrm{Cu}_{1} \%$ at. were developed by gas-atomization. Obtained powders in size $50-80 \mu \mathrm{m}$ were annealed at $\mathrm{T}_{\mathrm{g}}$ and $\mathrm{T}_{\mathrm{x}}$ of each alloy. Then SEM observation, EDS analyses, differential thermal analysis, X-ray diffraction, nanoindentation, Mössbauer, and magnetic properties research was carried out for as-atomized and annealed states. The gas atomization method proved to be an efficient method for manufacturing Co-based metallic glasses. The obtained powder particles were spherical and chemically homogeneous. Annealing resulted in an increase of mechanical properties such as hardness and the elastic module of $\mathrm{Co}_{47.6} \mathrm{~B}_{21.9} \mathrm{Fe}_{20.4} \mathrm{Si}_{5.1} \mathrm{Nb}_{5} \%$ at and $\mathrm{Co}_{42} \mathrm{~B}_{26.5} \mathrm{Fe}_{20} \mathrm{Ta}_{5.5} \mathrm{Si}_{5} \mathrm{Cu}_{1} \%$, which was caused by crystallization. The magnetic study shows that $\mathrm{Co}_{47.6} \mathrm{~B}_{21.9} \mathrm{Fe}_{20.4} \mathrm{Si}_{5.1} \mathrm{Nb}_{5}$ and $\mathrm{Co}_{42} \mathrm{~B}_{26.5} \mathrm{Fe}_{20} \mathrm{Ta}_{5.5} \mathrm{Si}_{5} \mathrm{Cu}_{1}$ are soft magnetic and semi-hard magnetic materials, respectively.
\end{abstract}

Keywords: co-based amorphous alloy; annealing; hardness; elastic module; magnetic properties; Mössbauer; amorphous alloy; metallic glass

\section{Introduction}

Amorphous alloys are a specific group of metal alloys in which the structure of the atoms that build solid-state objects is arranged without repeating the long-range order [1,2]. To obtain that state, the melted alloy needs to be cooled at a speed higher than the critical cooling rate. This cooling stops dynamic atom diffusion and enables the development of an amorphous solid-state structure of a metal alloy [3].

One of the methods that ensure cooling with a high enough speed is the gas atomization shown in Figure 1. Researchers [3-5] proved that atomization is a proper method to prepare amorphous alloys in a powder form. However, research shows that fully vitrification of powders depends on the size of obtained particles [6] and glass-forming ability of the processed alloy [7]. In article [8] researchers were able to simulate an atomization process for a Fe-based alloy with high glass forming ability. The simulation results of particle size distribution were confirmed by experimental results. Experimenters show a correlation between the pressure of the gas with particle size distribution. Obtained powders were fully amorphous for particle size $25-45 \mu \mathrm{m}$. 


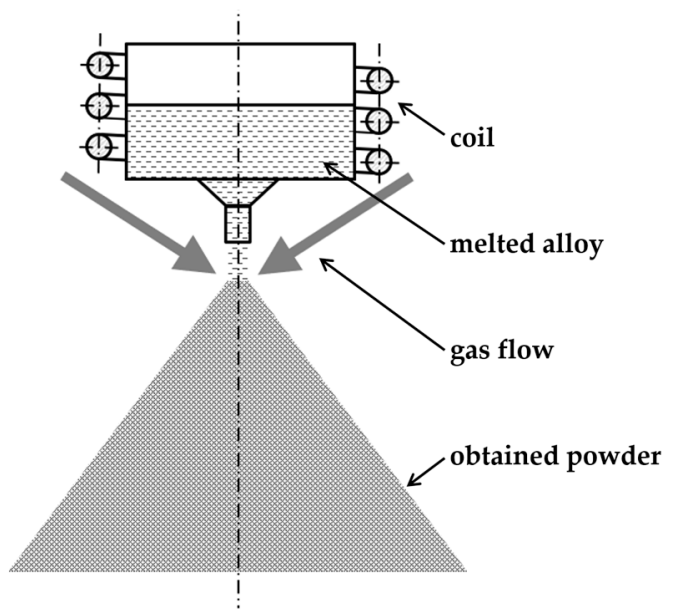

Figure 1. Schematic of the atomization process.

Gas atomization allows obtaining spherical and chemically homogeneous powder particles, which is essential to keep the high glass forming ability of the alloy. While new methods such as in-situ alloying of blended powder [9] is cost-effective, it often requires heat treatment to homogenize the chemical composition, which is unfavourable for metallic glasses.

Furthermore, powders obtained through atomization were successfully exploited in the production of bulk amorphous glasses by additive manufacturing. Ref. [10] reported efficiently produced samples by selective laser melting using gas-atomized powder (10-90 $\mu \mathrm{m}$ particles size) of Ti-based alloys with high glass-forming ability (critical casting thickness up to $7 \mathrm{~mm}$ ). Remarkably, in [10] research did not obtain the amorphous structure of the alloy by atomization (powder form), while obtained SLM samples from that powder had an amorphous structure. In [11] for SLM Fe-based amorphous alloys were used in form of particles size 2-53 $\mu \mathrm{m}$ received by gas atomization. Like before, the powder was a particular crystal-the volume of the crystalline phase was $10.1 \%$, but the parts of a developed sample were nearly almost amorphous.

Additive manufacturing is a technology also considered as a solution for the problem with critical raw materials. The latest review article [12] reports that additive manufacturing prevents developing waste through the production process and can change the whole chain that starts from suppling to distribution, which will occur in a much better situation of the critical raw materials market.

The atomization process is also in the interest of researchers to produce high entropy alloys $[13,14]$, which shows that atomization is a process suitable for a wide range of materials and worth studying more precise for materials from different groups. Moreover, many powders developed through this process are suitable to use as a feedstock for additive manufacturing [15]. In this article, amorphous metals obtained thou atomization will be tested.

The amorphous state of the alloy provides properties different from those of classic alloys with crystal/polycrystal structure [16]. With that order of atoms, different from the 'classic' alloys used in the global market, amorphous alloys give new possibilities of obtaining material harder and more durable with a young module with higher, better anticorrosion properties, and enormous good magnetic properties. That interest in amorphous alloys started when the first amorphous alloy was established by Klement [17] in 1960 and has lasted until now $[5,18]$.

The cobalt-based amorphous alloys investigated in this work have relatively good glass forming ability (GFA). In [19] CoMoPB rods achieve $4.5 \mathrm{~mm}$ of critical diameter, and in [20] even $5.0 \mathrm{~mm}$ for the CoFeNiBSiNb alloy. Other parameters related to GFA, namely, the supercooled liquid region $\left(\Delta \mathrm{T}_{\mathrm{x}}\right)$ for some Co-based alloys can even reach $111 \pm 5{ }^{\circ} \mathrm{C}$ [21]. This very good GFA of Co-based alloys allows different shape samples 
to be developed for research. As described above, the researchers were working on bulk metallic glasses (BMG) rods made using the copper mold injection casting method, but researchers also successfully obtained ribbons by melt spinning processes [22,23]. A more interesting shape, which was also studied in this work, is the powder form of an amorphous Co-based alloy. In [5] the researchers reported that they successfully obtained a powder of Co-based alloy by gas atomization, the same technology as used in this work. In addition, powder from [4] was used to develop an amorphous coating by laser cladding, so it is the next possibility of a form of Co-based alloys (amorphous coatings). However, researchers are still working on the BMG made by additive manufacturing. Although, successfully made by SLM BMG of other amorphous alloys and printing layers from Co-based alloys (laser cladding) implies that printing BMG Co-based amorphous alloys is possible.

Amorphous alloys based on Cobalt are distinguished by their very high hardness. The (CoFe)YB rods in [24] establishes $1336 \mathrm{HV}$ (100 g load, dwell time $10 \mathrm{~s})$ and in [25] CoNiTaB even 1410 HV (load 5 N, 10 s dwell time).

Taking into account that $\mathrm{Co}$ is a natural ferromagnetic material with a magnetic moment of 1.7-1.75 $\mu \mathrm{B}$. Moreover, this element is characterized by spin-orbit coupling stronger than pure iron and it is extremely important during designing materials for practical applications, i.e., small size inductor footprint or transformers [26,27]. CoFeSiB soft magnetic alloys are excellent candidates for such applications due to high electrical resistivity. The most popular soft magnetic Co-based alloy is a material called Vitrovac and its modifications $[28,29]$ which are characterized by relatively low coercivity, high saturation magnetization, low eddy current and high magnetic permeability.

It was observed that the Co-based alloys reduced Barkhausen jumps on the magnetic field in toroidal samples from $\lambda s=30 \cdot 10^{-6}$ for $\mathrm{Fe}_{84} \mathrm{~B}_{16}$ to $\lambda \mathrm{s}=10^{-6}$ for $\mathrm{Co}_{70} \mathrm{Fe}_{5} \mathrm{Si}_{15} \mathrm{~B}_{10}$ [30].

Recently, Nosenko and coworkers [31] have shown that selective $\mathrm{Cr}$ addition and optimum thermal treatment could decrease saturation induction, which is extremely important in the perspective application of Co-based alloys as supersensitive fluxgate sensors.

Co-based alloys are in the field of interest because of their mechanical and magnetic properties, which are very good, and are also investigated in this work. However, ribbons, rods, or layers are usually investigated, but there is not sufficient information about the properties of powders obtained by gas-atomization. Studying the properties of powder in the initial state and after annealing is important to understand further research on samples produced from powders like BMG performed by additive manufacturing or layers. In this work, $\mathrm{CoBFeSiNb}$ and $\mathrm{CoBFeTaSiCu}$ powders will be investigated.

\section{Materials and Methods}

In this work, two Co-based alloys were examined, first alloy- $\mathrm{Co}_{47.6} \mathrm{~B}_{21.9} \mathrm{Fe}_{20.4} \mathrm{Si}_{5.1} \mathrm{Nb}_{5} \%$ at, $\mathrm{Co}_{58.6} \mathrm{~B}_{4.9} \mathrm{Fe}_{23.8} \mathrm{Si}_{3.0} \mathrm{Nb}_{9.7} \%$ wg and second alloy- $\mathrm{Co}_{42} \mathrm{~B}_{26.5} \mathrm{Fe}_{20} \mathrm{Ta}_{5.5} \mathrm{Si}_{5} \mathrm{Cu}_{1} \%$ at, $\mathrm{Co}_{48.8} \mathrm{~B}_{5.6}$ $\mathrm{Fe}_{22} \mathrm{Ta}_{19.6} \mathrm{Si}_{2.8} \mathrm{Cu}_{1.3} \% \mathrm{wg}$. Alloys used in this research were obtained by alloying pure chemical elements: Co (99.99\%), Fe (99.97\%), B (99.9\%), Si (99.999\%), Nb (99.95\%), Cu (99.999\%), $\mathrm{Ta}(99.995 \%)$. The precise composition of the alloys is shown in Table 1.

Table 1. Chemical composition of the alloys in this work and prunes of the elements used for alloying.

\begin{tabular}{cccccccc}
\hline \multicolumn{1}{c}{} & \multicolumn{7}{c}{ Elements } \\
\hline First Alloy & Cobalt & Iron & Boron & Silicon & Niobium & Copper & Tantalum \\
\hline \% at. & 47.60 & 20.40 & 21.90 & 5.10 & 5.00 & 0.00 & 0.00 \\
\% wg. & 58.58 & 23.79 & 4.94 & 2.99 & 9.70 & 0.00 & 0.00 \\
Second Alloy & - & - & - & - & - & - & 1.00 \\
\hline \% at. & 42.00 & 20.00 & 26.50 & 5.00 & 0.00 & 5.50 \\
\% wg. & 48.75 & 22.00 & 5.64 & 2.77 & 0.00 & 1.25 & 19.60 \\
\% at. & 99.99 & 99.97 & 99.9 & 99.999 & 99.95 & 99.999 & 99.995 \\
\hline
\end{tabular}


Alloying was performed in an induction vacuum furnace VIM-LAB 50-60. Each alloy was maintained at high temperature for $1 \mathrm{~h}$ in the furnace to melt and mix all elements and then cast. After alloying, the cast bars were remelted under vacuum in a crucible, and then the metal was atomized using a jet of high-pressure argon. The powders obtained were sieved using vibrating sieves with a grid of 80,50 and $20 \mu \mathrm{m}$. Then fractions $20-50 \mu \mathrm{m}$ and 50-80 $\mu \mathrm{m}$ were selected for further investigations. The granulations obtained by sieving were analyzed by liquid particle size analysis (PSA) with the Anton Parr Particle Size Analyzer PSA 1190, Anton Paar GmbH, 8054 Graz, Austria. Obscuration of all measurements was set between $5-15 \%$. Before measurements were made, ultrasound dispersions of the samples were performed. The reconstruction mode was Fraunhofer. Optical and chemical composition analyses of the obtained particles were carried out by Scanning Electron Microscopy (SEM) Tescan Vega with Energy Dispersive Spectroscopy (EDS), module with material and topographic contrast (BSE and SE), TESCAN ORSAY HOLDING, a.s., Brno, Czech Republic. The acceleration voltage of the electrons for analysis was set at 20V. The amorphous state of the alloys and the presence of the crystalline phase were investigated by X-ray diffraction (XRD) using Rigaku Ultima IV Diffractometer, Rigaku Corporation, Tokyo, Japan with $\mathrm{Cu} K \alpha$ irradiation $(\lambda=1.5406 \AA)$. The range of $\mathrm{X}$-ray scanning was $15-95^{\circ} 2 \theta$ with a step of $0.05^{\circ}$. The electric parameters used for the analysis were $40 \mathrm{kV} / 40 \mathrm{mV}$. To establish the onset of the temperature of glass transition $\left(\mathrm{T}_{\mathrm{g}}\right)$ and crystallization $\left(\mathrm{T}_{\mathrm{x}}\right.$ ) Differential Thermal Analysis (DTA) was performed on STA 449 F3 Jupiter by NETZSCH factory thermal analyzer, NETZSCH-Gerätebau GmbH, 95100 Selb, Germany. The heating rate for DTA was $40 \mathrm{C} / \mathrm{min}$. The above-described characterization of two granulations of each Co-based alloy leads to focus on 50-80 $\mu \mathrm{m}$ powder granulation for the next step of the experiment. That next step included the annealing of the samples. The 50-80 $\mu \mathrm{m}$ particle size powder was divided into 3 groups. The first group was powder particles in the initial state- as-atomized, the second group was annealed at $\mathrm{T}_{\mathrm{g}}$ and the third group was annealed at $T_{x}$, respectively, and the temperatures were matched for the first and second alloy. The samples were annealed for $20 \mathrm{~min}$ in an atmosphere of inert gas (argon) in a Lt15/12/C450 Nabertherm furnace, Nabertherm GmbH, 28865 Lilienthal, Germany. Characteristic temperatures $\left(T_{g}\right.$ and $\left.T_{x}\right)$ were taken into account in this research because in those temperatures usually the biggest changes in mechanical parameters occurred. In $[32,33]$ the first biggest change in hardness value of amorphous samples was observed between samples annealed at peak of $T_{x}$ and annealed at $T_{g}$. The first noticeable change in fracture toughness and fracture mechanism of samples were observed between samples as-cast and annealed at $\mathrm{T}_{\mathrm{g}}$.

The time of annealing across the literature has ranged from $5 \mathrm{~min}$ [34] to hours [35]. By experience, and the work of other researchers [36,37], it was decided that $20 \mathrm{~min}$ is proper to observe the first changes in properties of the examined samples in this research.

After the samples were annealed and cooled outside the furnace in an inert atmosphere, X-ray diffraction (XRD) and SEM tests were re-performed. Next, the mechanical parameters of these three groups of samples were examined by using nanoindentation. Nanoindentations were taken on an Anton Paar Tester NHT3 on the STeP 4 platform with Berkovich type tip, Anton Paar GmbH, 8054 Graz, Austria, calibrated before measurements on fused silica samples. Measurements were taken at room temperature, the applied load was set at a level of $35 \mathrm{mN}$, a pause of $30 \mathrm{~s}$ was observed and rate of load and unloading was $70 \mathrm{mN} / \mathrm{min}$. The distance between the indentations was at least $1.5 \mathrm{x}$ the width of the indent. Calculations of the hardness and the elastic module were performed using the Oliver and Parr method [38]. Indentation hardness $\left(\mathrm{H}_{\mathrm{IT}}\right)$ was calculated from Equation (1) as a ratio of the maximum test force $\left(\mathrm{F}_{\max }\right)$ to the projected contact area $\left(\mathrm{A}_{\mathrm{p}}\right)$

$$
\mathrm{H}_{\mathrm{IT}}=\mathrm{F}_{\max } / \mathrm{A}_{\mathrm{p}},
$$

$A_{p}$ for the Berkovich tip is calculated from Equation (2) as a square of the contact depth of the indent $\left(h_{c}\right)$ multiplied by $24.5 . h_{c}$ is measured as the maximum depth of the 
indent $\left(\mathrm{h}_{\max }\right)$, while $\mathrm{F}_{\max }$ is obtained, and reduced by elastic deformation of the surface following Sneddon discovery [39] (3).

$$
\begin{gathered}
\mathrm{A}_{\mathrm{p}}=24.5 \mathrm{~h}_{\mathrm{c}}{ }^{2}, \\
\mathrm{~h}_{\mathrm{c}}=\mathrm{h}_{\max }-0.75 \mathrm{~F}_{\max } / \mathrm{S},
\end{gathered}
$$

$\mathrm{S}$ in (3) represents the contact stiffness calculated as a slope of the plot during unloading. To convert the indentation hardness from MPa to Vickers (HV) the (4) equations were used (proper for Berkovich indenter tip).

$$
\mathrm{HV}_{\mathrm{IT}} \approx \mathrm{H}_{\mathrm{IT}} / 10.80,
$$

Elastic indentation module $\left(\mathrm{E}_{\mathrm{IT}}\right)$ was calculated using Equation (5), where: $v_{\mathrm{S}}, v_{\mathrm{i}^{-}}$ Poisson's ratio of sample and indenter, respectively, $\mathrm{E}_{\mathrm{i}}$ - reduced elastic module and indenter elastic module, respectively.

$$
\mathrm{E}_{\mathrm{IT}}=\left(1-v_{\mathrm{s}}{ }^{2}\right) /\left[1 / \mathrm{E}_{\mathrm{r}}-\left(1-v_{\mathrm{i}}{ }^{2}\right) / \mathrm{E}_{\mathrm{i}}\right],
$$

The values of $v_{i}$ and $E_{i}$ were taken from the documentation of the indenter delivered by the manufacturer. $v_{\mathrm{s}}$ was estimated by a review of the literature [40-42] and established at 0.315 .

The static hysteresis loops were measured at room temperature using a LakeShore VSM 7307 vibrating sample magnetometer, Lake Shore Cryotronics, Inc., Ohio 43082, USA, working under an external magnetic field up to 2T. The Mössbauer spectra were collected at room temperature using a Polon Mössbauer spectrometer, Polon, Warsaw, Poland, working in transmission geometry with the 57Co source in the Rh matrix (of the activity of $50 \mathrm{mCi}$ ). The studies were carried out on samples crushed to the powder in order to obtain a representation of the entire volume. The analysis was performed using a thin absorber approximation. The Mössbauer spectra were fitted with the WinNORMOS for Igor 6.04 package.

\section{Results}

\subsection{Particle Size Distribution}

Obtained through the alloying of chemical elements and atomization, Co-based powders of the first and second alloys form regular, spheric-shaped particles. By sieving the first and second alloy, two granulations to test, $20-50 \mu \mathrm{m}$ and $50-80 \mu \mathrm{m}$ were received successfully. The results of the particle size analysis showed that $50 \%$ of the particle size (D50) for the granulation of 20-50 $\mu \mathrm{m}$ granulation had a diameter less than or equal to $31.41 \mu \mathrm{m}$ and $29.43 \mu \mathrm{m}$, for the first and second alloys, respectively. D50 for 50-80 $\mu \mathrm{m}$ sets on $59.19 \mu \mathrm{m}$ and $63.50 \mu \mathrm{m}$, analogously. The analysis plots and images of the tested samples are shown in Figure 2. Further research was carried out on a higher granulation of alloys- $50-80 \mu \mathrm{m}$. 


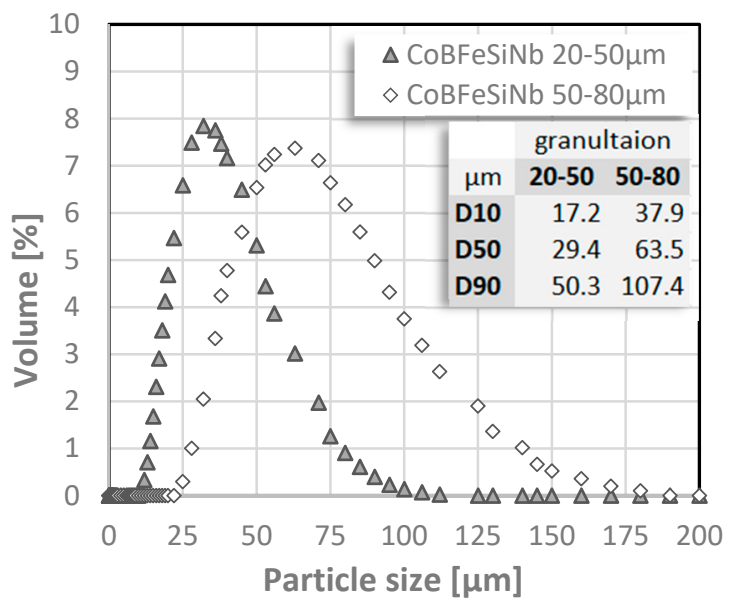

(a)

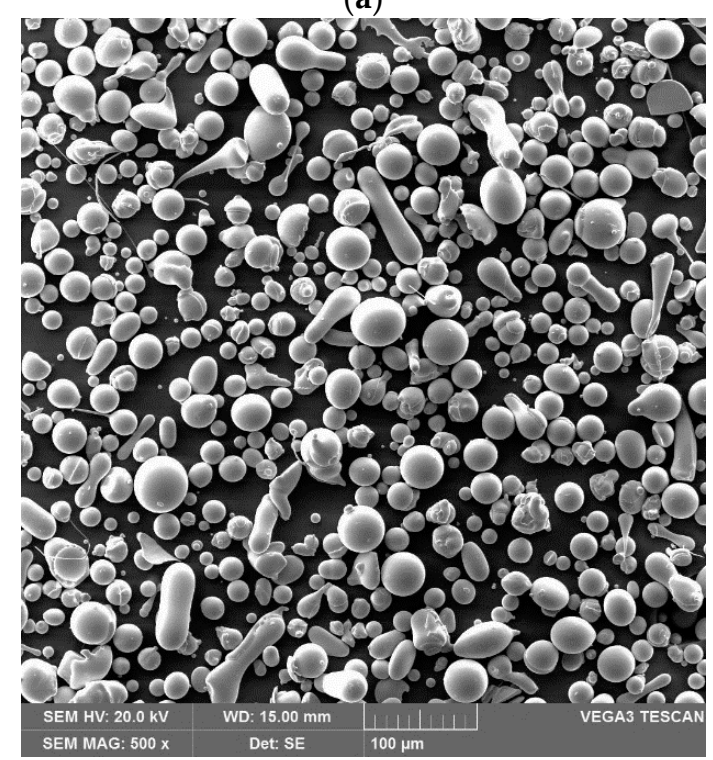

(c) $\mathrm{C}_{47.6} \mathrm{~B}_{21.9} . \mathrm{Fe}_{20.4 \mathrm{Si}} . \mathrm{N} \mathrm{Nb}_{5} 20-50 \mu \mathrm{m}$

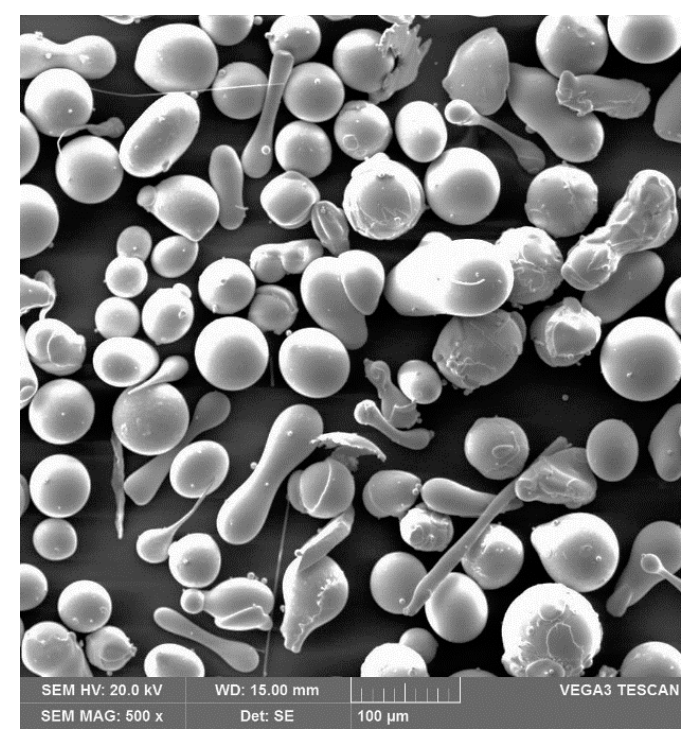

(e) $\mathrm{C}_{47.6} \mathrm{~B}_{21.9} . \mathrm{Fe}_{20.4 \mathrm{Si}} .1 \mathrm{Nb}_{5} 50-80 \mu \mathrm{m}$

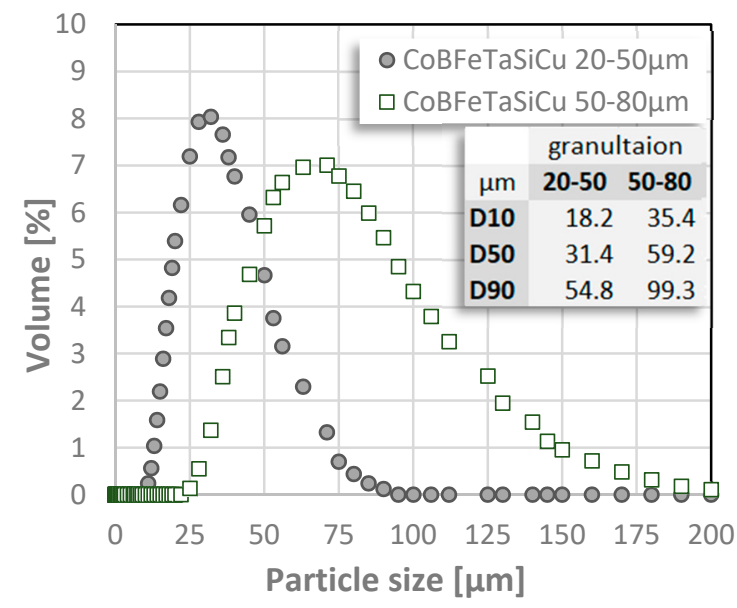

(b)

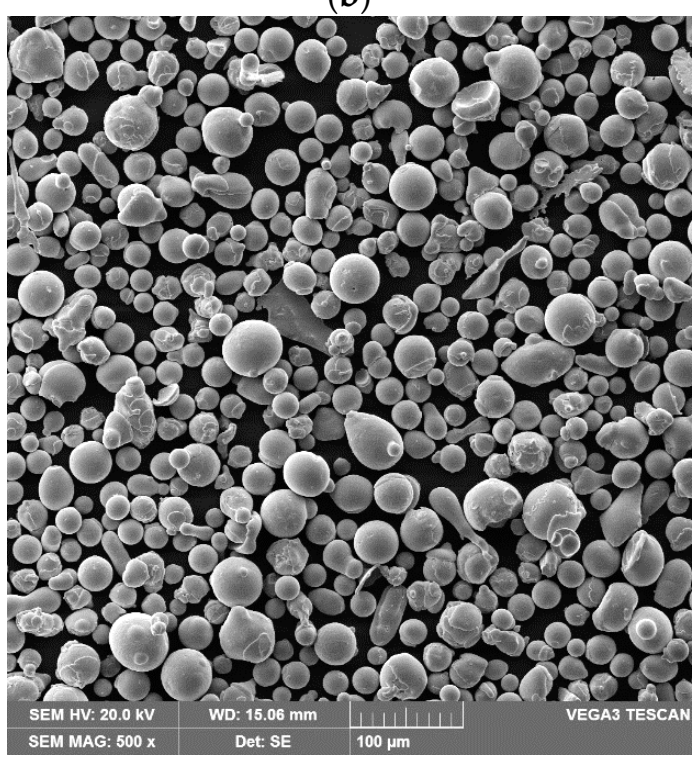

(d) $\mathrm{CO}_{42} \mathrm{~B}_{26.5} \mathrm{Fe}_{20} \mathrm{Ta}{ }_{5.5} \mathrm{Si}_{5} \mathrm{Cu}{ }_{1} 20-50 \mu \mathrm{m}$

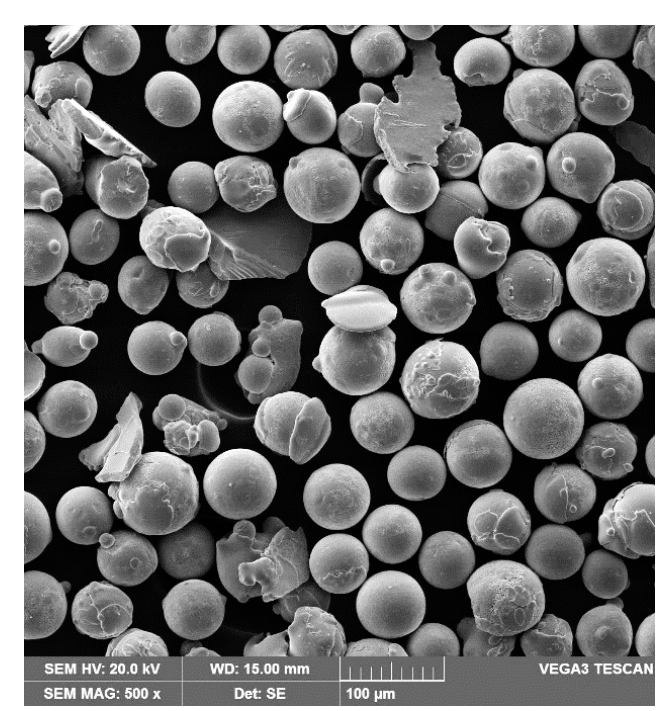

(f) $\mathrm{CO}_{42} \mathrm{~B}_{26.5} \mathrm{Fe}_{20} \mathrm{Ta}_{5.5 \mathrm{~S}} \mathrm{Si}_{5} \mathrm{Cu} 150-80 \mu \mathrm{m}$

Figure 2. Particle size analysis of (a) $\mathrm{Co}_{47.6} \mathrm{~B}_{21.9} \mathrm{Fe}_{20.4} \mathrm{Si}_{5.1} \mathrm{Nb}_{5}$ and (b) $\mathrm{Co} 42 \mathrm{~B} 26.5 \mathrm{Fe} 20.0 \mathrm{Ta} 5.5 \mathrm{Si} 5 \mathrm{Cu} 1 \%$ at fraction $20-50$ and $50-80 \mu \mathrm{m}$. (c-f) Example of alloys analyzed with SEM SE mag. $\times 500$. 


\subsection{EDS Analyzes/Chemical Composition Homogeneity of Particles}

SEM EDS analysis has shown a steady level of the amount of each chemical element inside the particles of both alloys. For the first alloy, the maximum difference between the maximum and minimum concentrations of each element was $2.5 \%$. For the second alloy, maximum differences were $7.6 \%$ for $\mathrm{Co}$ and around $5 \%$ for $\mathrm{Fe}$ and $\mathrm{Ta}$. For the rest of the elements in the second alloy, there was less than a $2.5 \%$ difference between the maximum and minimum concentrations. $\mathrm{O}$ and $\mathrm{C}$ rising on the edges of the graph came from the background of the particles. The described analysis and images of the analyzed metallographic section of the particles are shown in Figure 3.

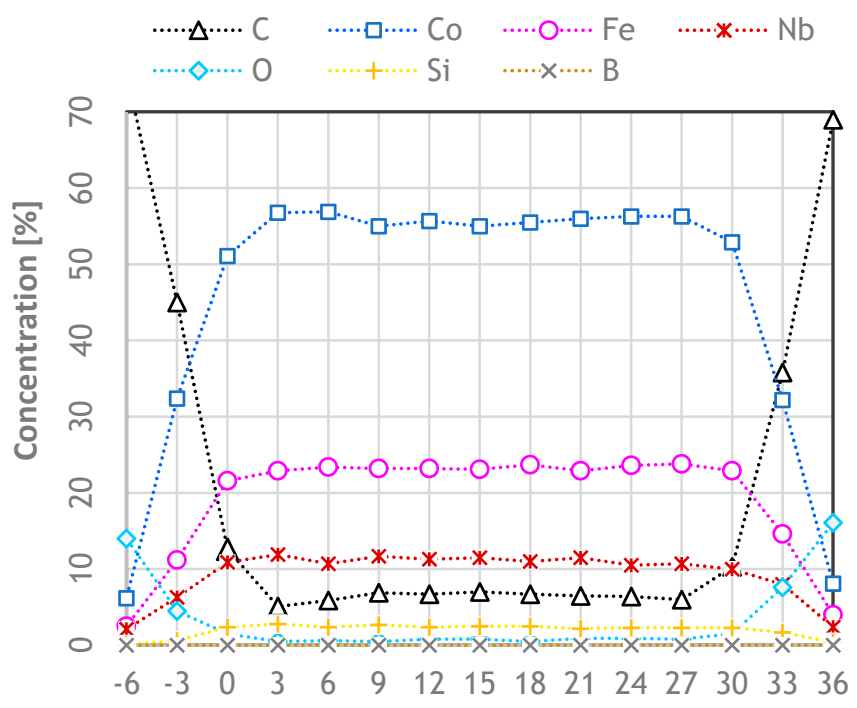

Distance from left surface [ $\mu \mathrm{m}]$

(a)

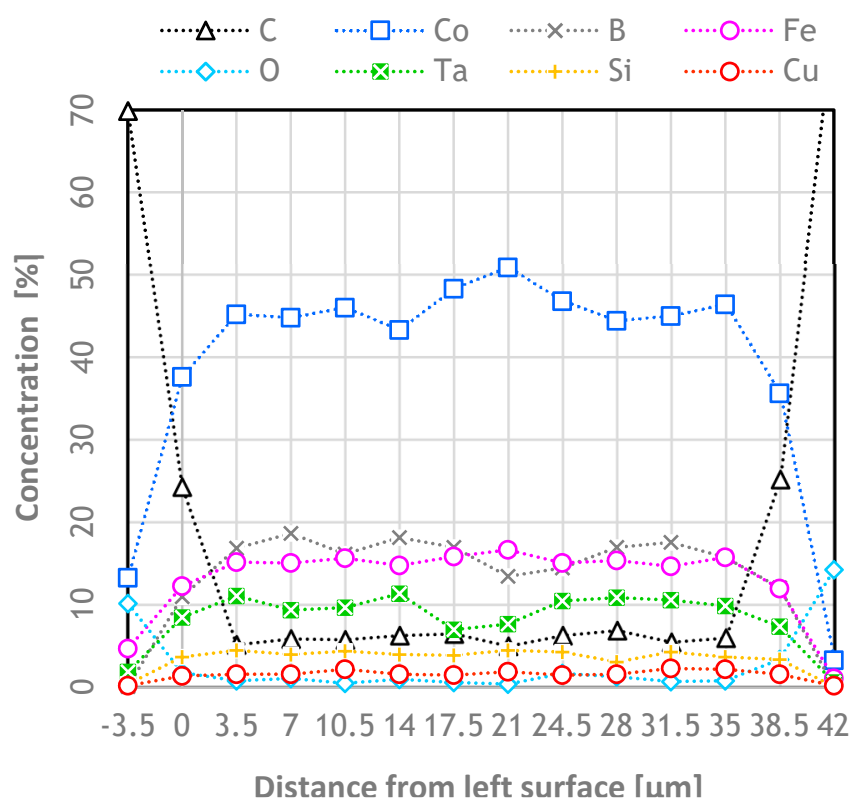

(c)

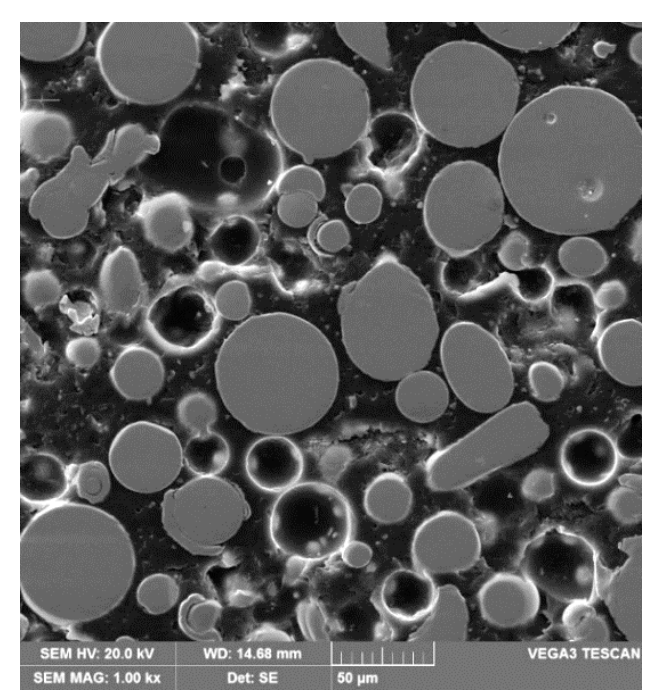

(b)

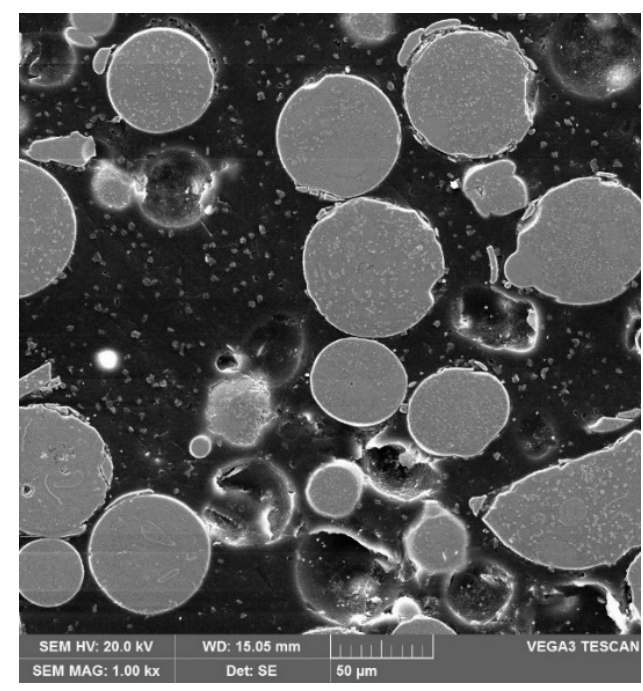

(d)

Figure 3. Example of EDS analysis of chemical composition homogeneity and SEM image of analyzed metallography section of $(\mathbf{a}, \mathbf{b}) \mathrm{Co}_{47.6} \mathrm{~B}_{21.9} \mathrm{Fe}_{20.4} \mathrm{Si}_{5.1} \mathrm{Nb}_{5} \%$ at. and $(\mathbf{c}, \mathbf{d}) \mathrm{Co}_{42} \mathrm{~B}_{26.5} \mathrm{Fe}_{20.0} \mathrm{Ta}_{5.5} \mathrm{Si}_{5} \mathrm{Cu}_{1} \%$ at. 


\subsection{Differential Thermal Analysis}

Conducting DTA of the first alloy shows the existence of an exothermal peak corresponding to the temperature of glass transition the $\mathrm{T}_{\mathrm{g}}$ and set at $598^{\circ} \mathrm{C}$. The next two exothermic peaks were observed, and the first one onset was $656^{\circ} \mathrm{C}$. The last peak with two maxims was endothermic and corresponded to the process of melting $\left(\mathrm{T}_{\mathrm{m}}\right)$ - onset at $1074{ }^{\circ} \mathrm{C}$. Analysis by DTA second alloying did not point out $\mathrm{Tg}$, but by studying the literature the $\mathrm{T}_{\mathrm{g}}$ of the second alloy was established at $545{ }^{\circ} \mathrm{C}$ for the next steps of the experiment [43]. However, three exothermic peaks were observed for the second alloy, and the first of them has an onset at $595^{\circ} \mathrm{C}$. The endothermal peak occurred at $1069^{\circ} \mathrm{C}\left(\mathrm{T}_{\mathrm{m}}\right)$ The DTA plot printed after the analysis is shown in Figure 4. The registered temperatures are shown in Table 2.

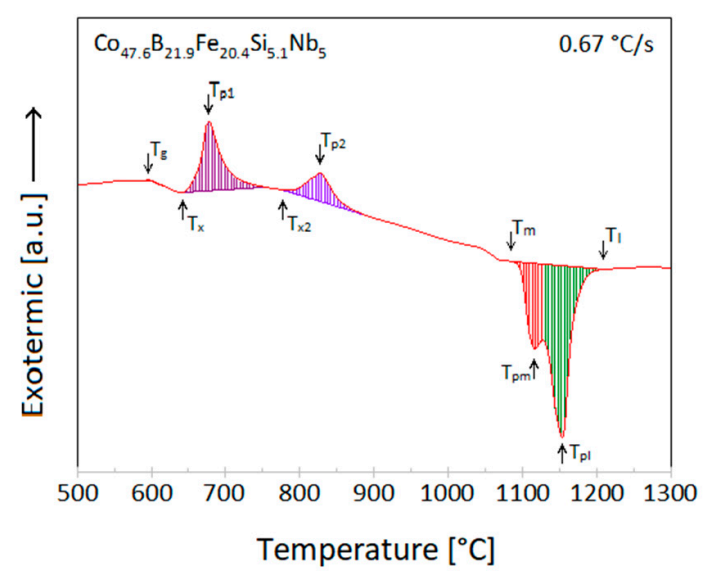

(a)

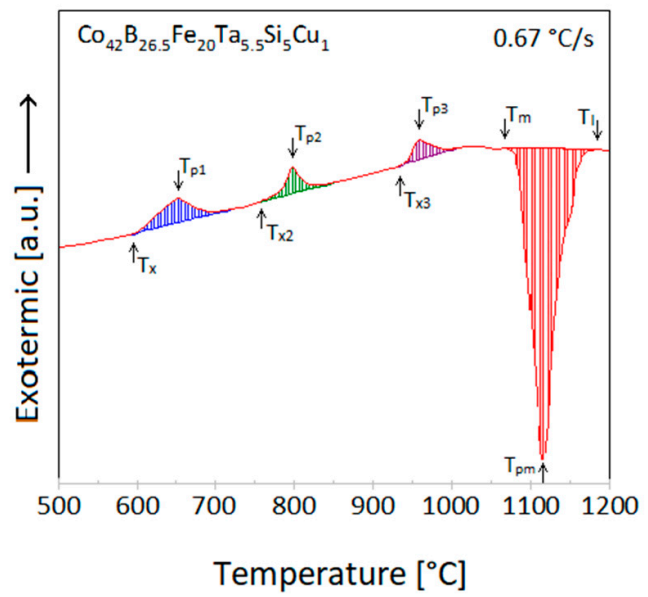

(b)

Figure 4. Differential Thermal Analysis (DTA) of two Co-based alloys.

Table 2. Characteristic temperature of $\mathrm{Co}_{47.6} \mathrm{~B}_{21.9} \mathrm{Fe}_{20.4} \mathrm{Si}_{5.1} \mathrm{Nb}_{5}$ and $\mathrm{Co}_{42} \mathrm{~B}_{26.5} \mathrm{Fe}_{20} \mathrm{Ta}_{5.5} \mathrm{Si}_{5} \mathrm{Cu}_{1}$.

\begin{tabular}{cccccccc}
\hline \multicolumn{1}{c}{ Temperature $\left[{ }^{\circ} \mathrm{C}\right]$} & $\mathbf{T}_{\mathbf{g}}$ & $\mathbf{T}_{\mathbf{x}}$ & $\mathbf{T}_{\mathbf{x} 2}$ & $\mathbf{T}_{\mathbf{x} 3}$ & $\Delta \mathbf{T}_{\mathbf{x}}$ & $\mathbf{T}_{\mathbf{m}}$ & $\mathbf{T}_{\mathbf{1}}$ \\
\hline $\mathrm{Co}_{47.6} \mathrm{~B}_{21.9} \mathrm{Fe}_{20.4} \mathrm{Si}_{5.1} \mathrm{Nb}_{5}$ & 598 & 656 & 782 & - & 58 & 1074 & 1144 \\
$\mathrm{Co}_{42} \mathrm{~B}_{26.5} \mathrm{Fe}_{20.0} \mathrm{Ta}_{5.5} \mathrm{Si}_{5} \mathrm{Cu}_{1}$ & - & 595 & 768 & 928 & - & 1069 & 1116 \\
\hline
\end{tabular}

\subsection{Annealing and X-ray Diffraction Test (of As-Atomized and Annealed Samples)}

Annealing of 50-80 $\mu \mathrm{m}$ powders of first and second alloys was carried out. XRD plots are shown in Figure 5. The XRD test of the first alloy in the atomized and annealed state at $\mathrm{Tg}$ did not show any diffraction peaks. Annealing at $\mathrm{T}_{\mathrm{x}}$ caused peaks of diffraction that may be indicated on $(\mathrm{Co}, \mathrm{Fe})_{2} \mathrm{~B}$. Particles of the second alloy in the as-atomized state showed some disturbances of the plot, which suggest that the atoms are more repeatable arranged than an as-atomized sample of the first alloy. The pattern of XRD of the second sample in the as-atomized state corresponds to $(\mathrm{Co}, \mathrm{Fe})_{2} \mathrm{~B}$. High intensity and broad peaks can be observed on XRD plots for the second alloy that was annealed at $T_{g}$ and annealed at $T_{x}$. Compared to the literature, [25-27], from analysis of the XRD patterns of diffracted $\mathrm{X}$-rays for the second alloy annealed at $\mathrm{T}_{\mathrm{g}}$, it can be concluded that these peaks correspond to $(\mathrm{Co}, \mathrm{Fe})_{2} \mathrm{~B}$ and some lower intense peaks indicated to $\alpha-(\mathrm{Co}, \mathrm{Fe})$. The last graph of the second alloy, for the powder annealed at $T_{x}$, had an instance and broad peaks indicating the presence of crystalline peaks of both $(\mathrm{Co}, \mathrm{Fe})_{2} \mathrm{~B}$ and $\alpha-(\mathrm{Co}, \mathrm{Fe})$. 


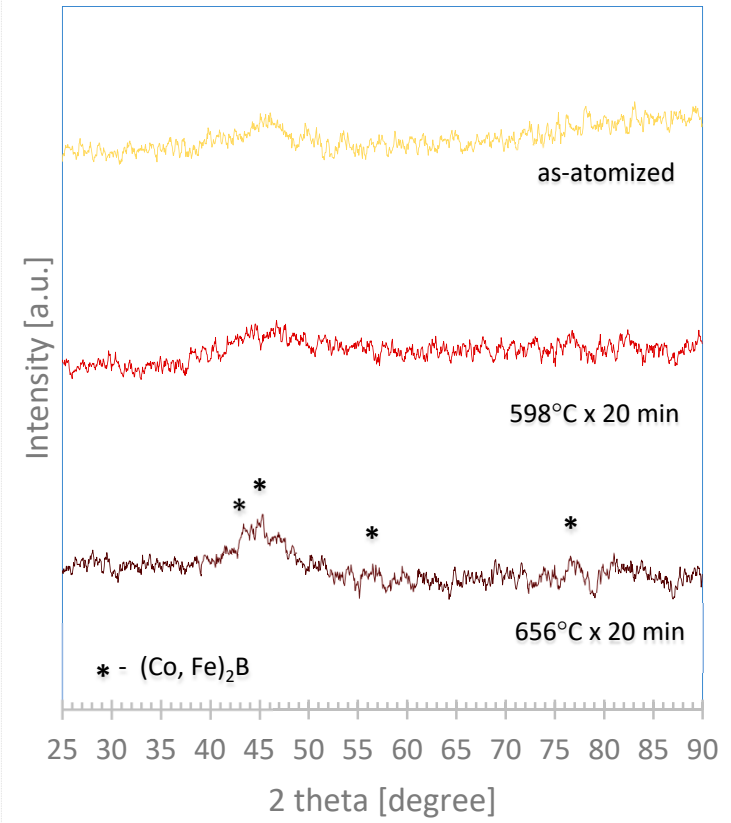

(a)

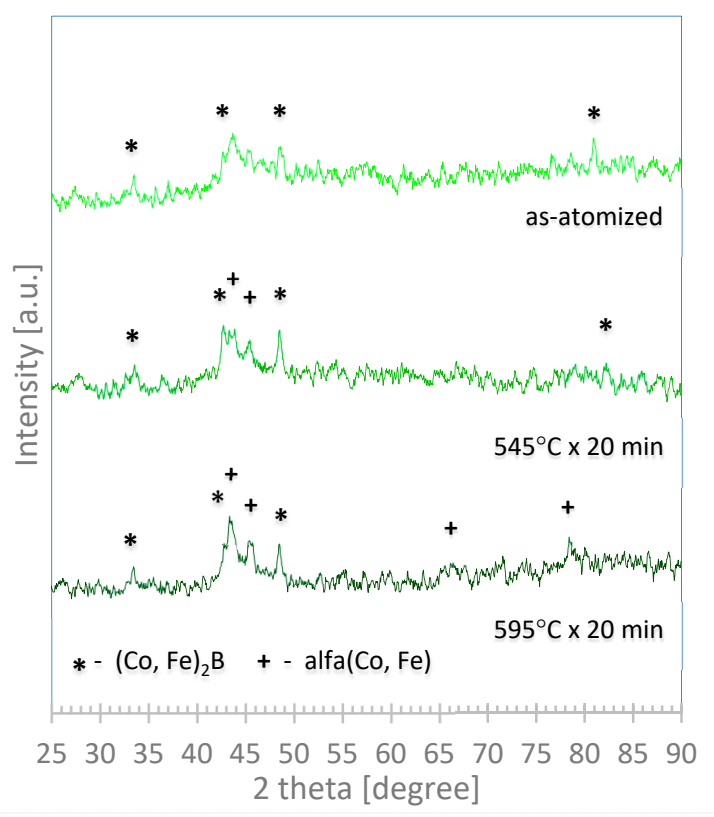

(b)

Figure 5. X-ray diffractogram plots of (a) $\mathrm{Co}_{47.6} \mathrm{~B}_{21.9} \mathrm{Fe}_{20.4} \mathrm{Si}_{5.1} \mathrm{Nb}_{5}$ and (b) $\mathrm{Co}_{42} \mathrm{~B}_{26.5} \mathrm{Fe}_{20} \mathrm{Ta}_{5.5} \mathrm{Si}_{5} \mathrm{Cu}_{1}$ powder as atomized, annealed at glass transition temperature $\left(\mathrm{T}_{\mathrm{g}}\right)$ and annealed at first crystallization temperature $\left(\mathrm{T}_{\mathrm{x}}\right)$.

\subsection{SEM Analysis}

Analyzed SEM samples of the as-atomized powder of the first alloy present regular spheric particles with some splats on the surfaces. However, no splats detached from the spheric particles were observed. The surface of the particles and splats were plain without any irregularities. The microscopic observation did not show any changes on the surface of the particles that occurred by annealing of the powder samples, neither at $T_{g}$ nor at $T_{x}$. The second alloy as-atomized powder SEM analysis also exhibits a regular spheric shape of the particles and presents some splats joined to the spheric particles. The surface of the particles was irregular. Like before, annealing at $T_{g}$ and $T_{x}$ of the second alloy did not cause visible changes on the particles. Representative samples of each powder are shown in Figure 6.

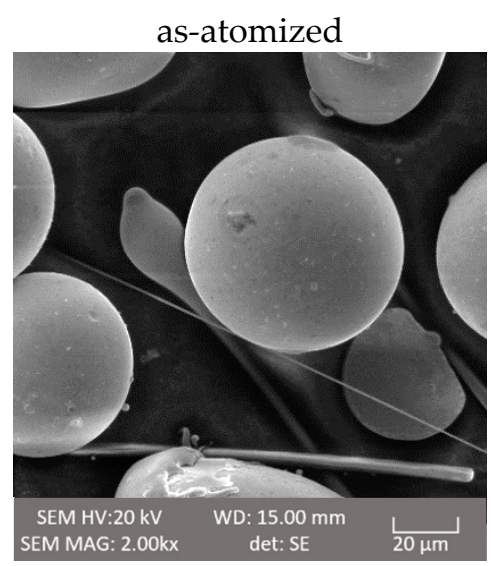

(a)

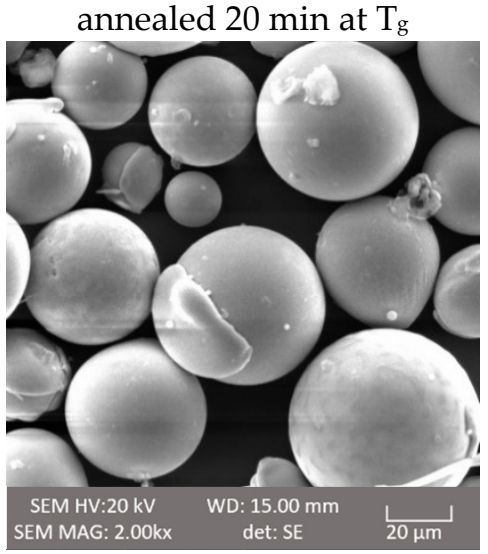

(b) annealed $20 \mathrm{~min}$ at $\mathrm{T}_{x}$

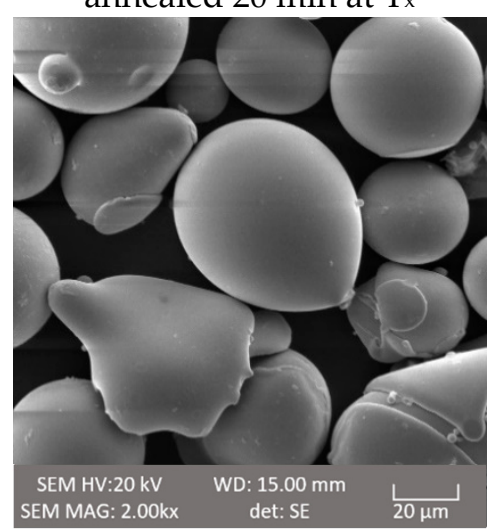

(c)

Figure 6. Cont. 


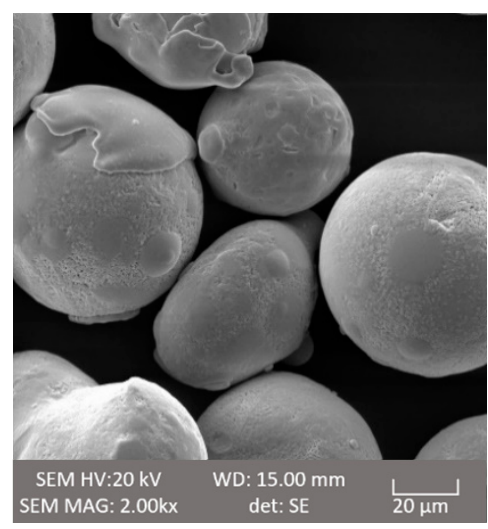

(d)

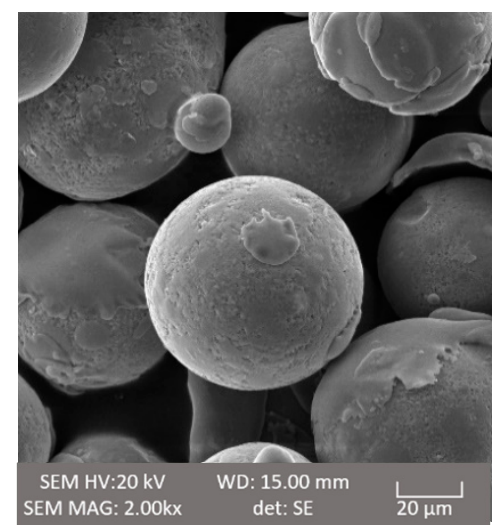

(e)

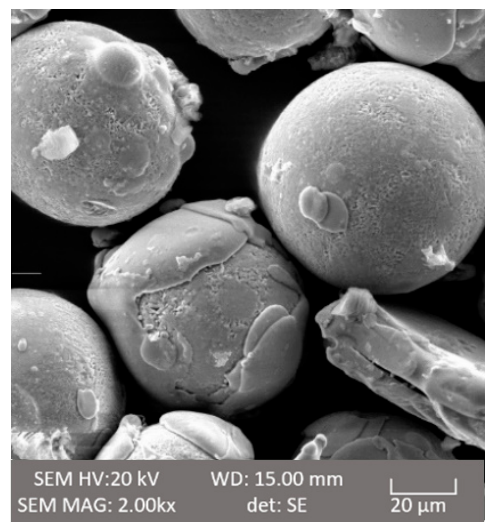

(f)

Figure 6. SEM image, topography contrast of $(\mathbf{a}-\mathbf{c}) \mathrm{Co}_{47.6} \mathrm{~B}_{21.9} \mathrm{Fe}_{20.4} \mathrm{Si}_{5.1} \mathrm{Nb}_{5},(\mathbf{d}, \mathbf{e}) \mathrm{Co}_{42} \mathrm{~B}_{26.5} \mathrm{Fe}_{20} \mathrm{Ta}_{5.5} \mathrm{Si}_{5} \mathrm{Cu}_{1}$; (a,d) powders as atomized, $(\mathbf{b}, \mathbf{e})$ annealed at glass transition temperature $\left(\mathrm{T}_{\mathrm{g}}\right),(\mathbf{c}, \mathbf{f})$ annealed at first crystallization temperature $\left(\mathrm{T}_{\mathrm{x}}\right)$.

\subsection{Nanoindetation}

The mean hardness $\left(\mathrm{H}_{\mathrm{IT}}\right)$ value of the second alloy calculated from nanoindentation tests for atomized particles was 16,768.64 MPa (or 1552.96 HV), for annealed at $\mathrm{T}_{\mathrm{g}}$ 18,562.29 MPa (1721.85 HV) and $\mathrm{T}_{\mathrm{x}} 19,463.81 \mathrm{MPa}(1221.52 \mathrm{HV})$. These results indicate that annealing in this experiment causes an increase in the mean hardness for annealing of $76.31 \mathrm{MPa}$ for annealing at $\mathrm{T}_{\mathrm{g}}$ and $149 \mathrm{MPa}$ for annealing at $\mathrm{T}_{\mathrm{x}}$. Likewise, the elastic indentation module increases after annealing as-atomized powder. $\mathrm{E}_{\mathrm{IT}}$ set on $139.54 \mathrm{GPa}$, 173.85 GPa and 182.5 GPa respectively, for the as-atomized, annealed at $\mathrm{T}_{\mathrm{g}}$ and annealed at $T_{x}$. The results described are shown in Table 3. Examples of plots obtained from nanoindentation and graphic results are shown in Figure 7.

Table 3. Results of the second alloy nanoindentation test in the as-atomized state, annealed at $\mathrm{T}_{\mathrm{g}}$ and $\mathrm{T}_{\mathrm{x}}$.

\begin{tabular}{|c|c|c|c|c|c|c|c|c|c|}
\hline \multirow[b]{2}{*}{$\begin{array}{l}\text { Parameter } \\
\text { Unit }\end{array}$} & \multicolumn{3}{|c|}{ As-Atomized } & \multicolumn{3}{|c|}{ Annealed at $T_{g}$} & \multicolumn{3}{|c|}{ Annealed at $T_{x}$} \\
\hline & $\begin{array}{l}\mathrm{H}_{\mathrm{IT}} \\
(\mathrm{MPa})\end{array}$ & $\begin{array}{l}\mathrm{HV}_{\mathrm{IT}} \\
(\mathrm{HV})\end{array}$ & $\begin{array}{c}\mathrm{E}_{\mathrm{IT}} \\
(\mathrm{GPa})\end{array}$ & $\begin{array}{l}\mathrm{H}_{\mathrm{IT}} \\
(\mathrm{MPa})\end{array}$ & $\begin{array}{l}\mathrm{HV}_{\mathrm{IT}} \\
(\mathrm{HV})\end{array}$ & $\begin{array}{c}\mathrm{E}_{\mathrm{IT}} \\
(\mathrm{GPa})\end{array}$ & $\begin{array}{c}\mathrm{H}_{\mathrm{IT}} \\
(\mathrm{MPa})\end{array}$ & $\begin{array}{l}\mathrm{HV}_{\mathrm{IT}} \\
(\mathrm{HV})\end{array}$ & $\begin{array}{c}\mathrm{E}_{\mathrm{IT}} \\
(\mathrm{GPa})\end{array}$ \\
\hline Mean & $16,768.6$ & 1553.0 & 139.5 & $18,592.3$ & 1721.9 & 173.0 & $19,463.8$ & 1802.6 & 182.5 \\
\hline $\begin{array}{l}\text { Standard } \\
\text { deviation }\end{array}$ & 1085.4 & 100.5 & 8.9 & 703.6 & 65.2 & 8.1 & 1221.5 & 113.1 & 5.0 \\
\hline $\begin{array}{l}\text { Coefficient of } \\
\text { variation [\%] }\end{array}$ & 6.5 & 6.5 & 6.4 & 3.8 & 3.8 & 4.7 & 6.3 & 6.3 & 2.7 \\
\hline
\end{tabular}

$\mathrm{H}_{\mathrm{IT}}$-indentation hardness, $\mathrm{HV}_{\mathrm{IT}}$-Vickers hardness calculated from indentation hardness $\mathrm{HV}_{\mathrm{IT}}=\mathrm{H}_{\mathrm{IT}} / 10.80, \mathrm{E}_{\mathrm{IT}}$-indentation elastic module. 


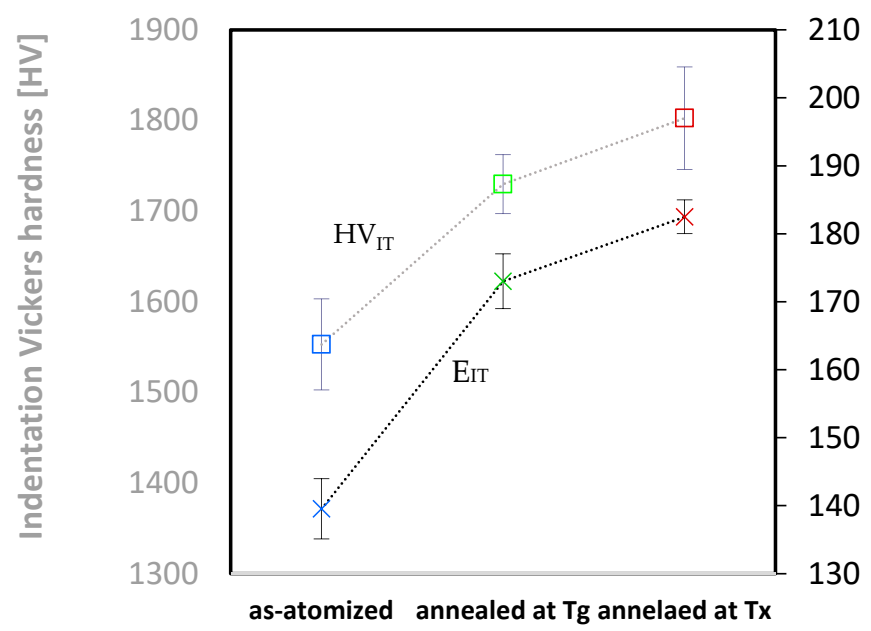

(a)

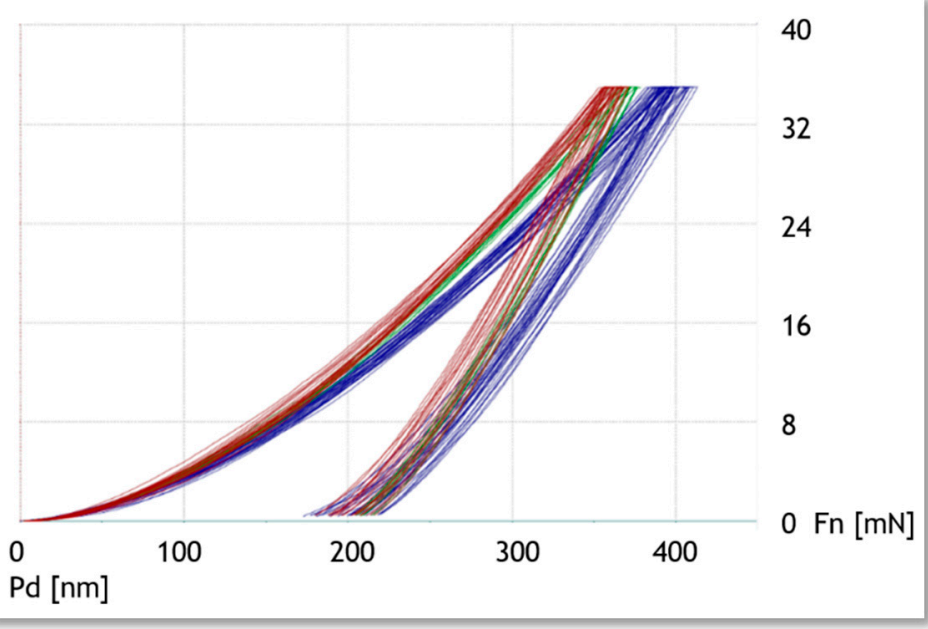

(b)

Figure 7. (a) Plots of the nanoindentation test, force to the depth of penetration (blue-as-atomized; green-annealed at $T_{g}$, glass transition temperature; brown- annealed at $T_{x}$, crystallization temperature), (b) graphic presentation of nanoindentation test results.

\subsection{Mössbauer Studies}

As is well known, the Mössbauer spectroscopy is a very sensitive method for the investigation of the structure and magnetic state of materials. X-ray diffraction revealed an amorphous structure; however, in the case of Mössbauer spectroscopy, some phases were detected. This difference is due to the sensitivities of each method. The measured spectrum of $\mathrm{Co}_{47.6} \mathrm{Fe}_{20.4} \mathrm{~B}_{21.9} \mathrm{Si}_{5.1} \mathrm{Nb}_{5}$ was deconvoluted in a doublet corresponding to the disordered Fe-based phase and in sextets that are related to $\mathrm{Fe}_{2} \mathrm{~B}$ and $\mathrm{Fe}-\mathrm{Nb}-\mathrm{B}$ phases. Taking into account analysis of annealed samples, a change in phase constitution was not observed; however, successive increase of $\mathrm{Fe}_{2} \mathrm{~B}$ phase at the expense of two other phases was detected. All parameters, such as, isomer shift IS, quadrupole splitting QS and hyperfine field induction Bhf for all studied samples were collected in Table 4. For the $\mathrm{Co}_{42} \mathrm{Cu}_{1} \mathrm{Fe}_{20} \mathrm{Ta}_{5.5} \mathrm{~B}_{26.5} \mathrm{Si}_{5}$ alloy samples, the Mössbauer spectra collected at room temperature were deconvoluted in three phases: Fe-Cu corresponding to paramagnetic doublet, $\mathrm{Fe}_{2} \mathrm{~B}$, and $\mathrm{Fe}-\mathrm{B}-\mathrm{Nb}$ corresponding to ferromagnetic sextets. The analysis of spectra of annealed samples expansion of $\mathrm{Fe}_{2} \mathrm{~B}$ phase at the expense of other two phases. Table 4 contains all parameters of the 
Mössbauer spectra. The room temperature Mössbauer spectrums of the as-atomized first and second alloy samples are shown in Figure 8.

Table 4. The parameters of the Mossbauer spectra of studied samples. D-doublet, S-Sextet.

\begin{tabular}{|c|c|c|c|c|c|c|}
\hline Component & IS (mm/s) & QS (mm/s) & B (T) & $\begin{array}{l}\text { FWHM } \\
(\mathrm{mm} / \mathrm{s})\end{array}$ & A $(\%)$ & Compound \\
\hline \multicolumn{7}{|c|}{$\mathrm{Co}_{47.6} \mathrm{~B}_{21.9} \mathrm{Fe}_{20.4} \mathrm{Si}_{5.1} \mathrm{Nb}_{5}$ as-atomized } \\
\hline D1 & 0.16 & 0.79 & - & 0.42 & 7 & Fe-based \\
\hline $\mathrm{S} 1$ & 0.16 & -0.02 & 23.4 & 0.32 & 5 & \multirow{2}{*}{$\mathrm{Fe}_{2} \mathrm{~B}$} \\
\hline S2 & 0.16 & -0.01 & 21.5 & 0.32 & 8 & \\
\hline S3 & 0.18 & -0.06 & 19.4 & 0.54 & 23 & \multirow{5}{*}{$\mathrm{Fe}-\mathrm{B}-\mathrm{Nb}$} \\
\hline S4 & 0.15 & -0.01 & 16.9 & 0.54 & 20 & \\
\hline S5 & 0.11 & 0.07 & 14.5 & 0.54 & 17 & \\
\hline S6 & 0.10 & 0.01 & 11.3 & 0.54 & 14 & \\
\hline S7 & 0.17 & 0.03 & 8.3 & 0.54 & 6 & \\
\hline \multicolumn{7}{|c|}{$\mathrm{Co}_{47.6} \mathrm{~B}_{21.9} \mathrm{Fe}_{20.4} \mathrm{Si}_{5.1} \mathrm{Nb}_{5}$ annealed at $\mathrm{T}=597^{\circ} \mathrm{C}$ for $20 \mathrm{~min}}$. \\
\hline D1 & 0.19 & 0.76 & - & 0.36 & 5 & Fe-based \\
\hline S1 & 0.15 & -0.02 & 23.5 & 0.32 & 7 & \multirow{2}{*}{$\mathrm{Fe}_{2} \mathrm{~B}$} \\
\hline S2 & 0.15 & -0.01 & 21.6 & 0.32 & 9 & \\
\hline S3 & 0.16 & -0.06 & 19.7 & 0.52 & 20 & \multirow{5}{*}{$\mathrm{Fe}-\mathrm{B}-\mathrm{Nb}$} \\
\hline S4 & 0.15 & -0.02 & 17.3 & 0.52 & 20 & \\
\hline S5 & 0.10 & 0.07 & 14.7 & 0.52 & 16 & \\
\hline S6 & 0.07 & 0.04 & 11.2 & 0.52 & 12 & \\
\hline S7 & 0.17 & 0.05 & 8.1 & 0.52 & 11 & \\
\hline \multicolumn{7}{|c|}{$\mathrm{Co}_{47.6} \mathrm{~B}_{21.9} \mathrm{Fe}_{20.4} \mathrm{Si}_{5.1} \mathrm{Nb}_{5}$ annealed at $\mathrm{T}=656^{\circ} \mathrm{C}$ for $20 \mathrm{~min}}$. \\
\hline D1 & 0.15 & 0.78 & - & 0.41 & 4 & Fe-based \\
\hline S1 & 0.17 & -0.02 & 23.3 & 0.32 & 9 & \multirow{2}{*}{$\mathrm{Fe}_{2} \mathrm{~B}$} \\
\hline $\mathrm{S} 2$ & 0.16 & -0.01 & 21.5 & 0.32 & 9 & \\
\hline S3 & 0.19 & -0.06 & 19.5 & 0.55 & 22 & \multirow{5}{*}{$\mathrm{Fe}-\mathrm{B}-\mathrm{Nb}$} \\
\hline $\mathrm{S} 4$ & 0.15 & -0.01 & 16.8 & 0.55 & 20 & \\
\hline S5 & 0.11 & 0.07 & 14.5 & 0.55 & 15 & \\
\hline S6 & 0.09 & 0.01 & 11.3 & 0.55 & 15 & \\
\hline S7 & 0.17 & 0.03 & 8.3 & 0.55 & 6 & \\
\hline \multicolumn{7}{|c|}{$\mathrm{Co}_{42} \mathrm{~B}_{26.5} \mathrm{Fe}_{20} \mathrm{Ta}_{5.5} \mathrm{Si}_{5} \mathrm{Cu}_{1}$ as- atomized } \\
\hline D1 & 0.22 & 0.44 & - & 0.43 & 24 & \multirow{2}{*}{$\mathrm{Fe}-\mathrm{Cu}$} \\
\hline D2 & 0.27 & 0.68 & - & 0.43 & 47 & \\
\hline $\mathrm{S} 1$ & 0.12 & 0.00 & 23.8 & 0.45 & 14 & \multirow{2}{*}{$\mathrm{Fe}_{2} \mathrm{~B}$} \\
\hline S2 & 0.13 & 0.00 & 21.7 & 0.45 & 8 & \\
\hline S3 & 0.21 & 0.00 & 19.1 & 0.59 & 7 & $\mathrm{Fe}-\mathrm{B}-\mathrm{Nb}$ \\
\hline
\end{tabular}


Table 4. Cont.

\begin{tabular}{|c|c|c|c|c|c|c|}
\hline Component & IS $(\mathrm{mm} / \mathrm{s})$ & QS (mm/s) & B (T) & $\begin{array}{l}\text { FWHM } \\
(\mathrm{mm} / \mathrm{s})\end{array}$ & A (\%) & Compound \\
\hline \multicolumn{7}{|c|}{$\mathrm{Co}_{42} \mathrm{~B}_{26.5} \mathrm{Fe}_{20} \mathrm{Ta}_{5.5} \mathrm{Si}_{5} \mathrm{Cu}_{1}$ annealed at $\mathrm{T}=545^{\circ} \mathrm{C}$ for $20 \mathrm{~min}}$. \\
\hline D1 & 0.21 & 0.41 & - & 0.41 & 18 & \multirow{2}{*}{$\mathrm{Fe}-\mathrm{Cu}$} \\
\hline D2 & 0.28 & 0.66 & - & 0.41 & 51 & \\
\hline $\mathrm{S} 1$ & 0.11 & 0.00 & 23.5 & 0.52 & 12 & \multirow{2}{*}{$\mathrm{Fe}_{2} \mathrm{~B}$} \\
\hline S2 & 0.09 & 0.00 & 21.5 & 0.52 & 12 & \\
\hline S3 & 0.21 & 0.00 & 13.9 & 0.52 & 6 & $\mathrm{Fe}-\mathrm{B}-\mathrm{Nb}$ \\
\hline \multicolumn{7}{|c|}{$\mathrm{Co}_{42} \mathrm{~B}_{26.5} \mathrm{Fe}_{20} \mathrm{Ta}_{5.5} \mathrm{Si}_{5} \mathrm{Cu}_{1}$ annealed at $\mathrm{T}=597^{\circ} \mathrm{C}$ for $20 \mathrm{~min}}$. \\
\hline D1 & 0.24 & 0.46 & - & 0.41 & 26 & \multirow{2}{*}{$\mathrm{Fe}-\mathrm{Cu}$} \\
\hline D2 & 0.28 & 0.68 & - & 0.41 & 40 & \\
\hline S1 & 0.11 & 0.00 & 23.8 & 0.39 & 10 & \multirow{2}{*}{$\mathrm{Fe}_{2} \mathrm{~B}$} \\
\hline S2 & 0.12 & 0.00 & 21.7 & 0.39 & 11 & \\
\hline S3 & 0.08 & 0.00 & 19.1 & 0.39 & 5 & \multirow{2}{*}{$\mathrm{Fe}-\mathrm{B}-\mathrm{Nb}$} \\
\hline $\mathrm{S} 4$ & 0.20 & 0.00 & 13.7 & 0.58 & 8 & \\
\hline
\end{tabular}

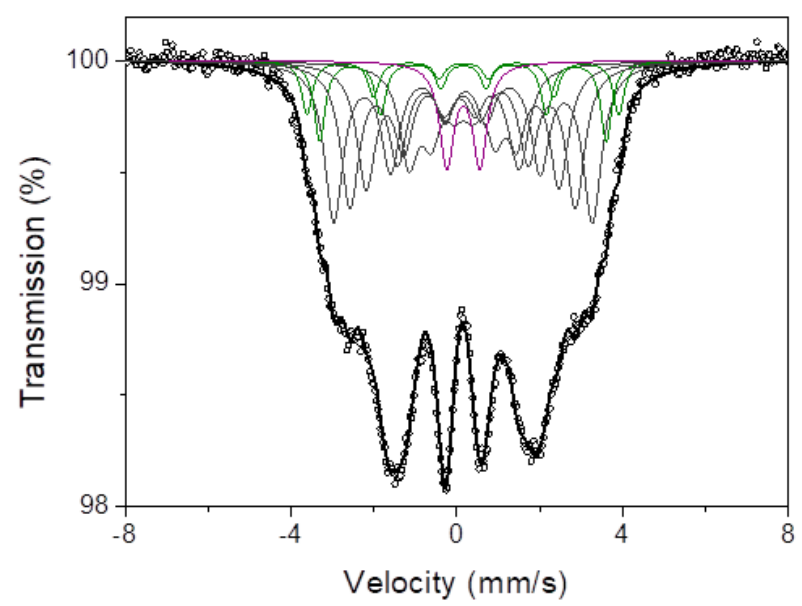

(a)

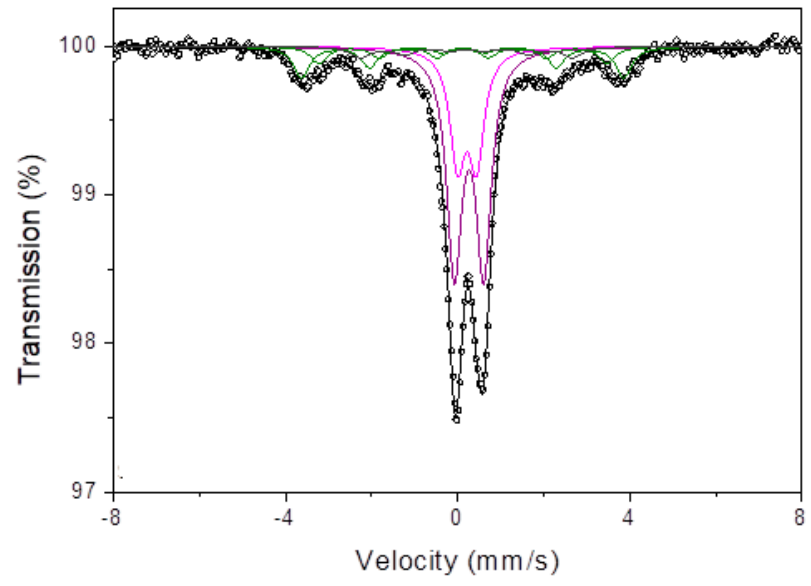

(b)

Figure 8. Analyzed Mössbauer spectrum of the as-atomized (a) $\mathrm{Co}_{47.6} \mathrm{~B}_{21.9} \mathrm{Fe}_{20.4} \mathrm{Si}_{5.1} \mathrm{Nb}_{5}$ and (b) $\mathrm{Co}_{42} \mathrm{~B}_{26.5} \mathrm{Fe}_{20} \mathrm{Ta}_{5.5} \mathrm{Si}_{5} \mathrm{Cu}_{1}$. 


\subsection{Magnetic Properties}

In order to reveal magnetic properties and classify the powder produced into some group of magnetic materials, the static hysteresis loops at room temperature were measured (Figure 9). In the case of samples of the $\mathrm{Co}_{47.6} \mathrm{~B}_{21.9} \mathrm{Fe}_{20.4} \mathrm{Si}_{5.1} \mathrm{Nb}_{5}$ alloy, the saturation magnetization is $59.4,63.6$ and $58.1 \mathrm{Am}^{2} / \mathrm{kg}$ for as-atomized, annealed at $597^{\circ} \mathrm{C}$ and $656^{\circ} \mathrm{C}$, respectively. The phase contained $\mathrm{Nb}$ and Ta were detected by Mössbauer spectroscopy due to its higher sensitivity compared to the XRD diffraction. The coercivity equalled 319,321 and $690 \mathrm{~A} / \mathrm{m}$. The saturation magnetization for $\mathrm{Co}_{42} \mathrm{~B}_{26.5} \mathrm{Fe}_{20} \mathrm{Ta}_{5.5} \mathrm{Si}_{5} \mathrm{Cu}_{1}$ alloy sets on the level of 20.6, 21.4 and $21.6 \mathrm{Am}^{2} / \mathrm{kg}$ for the as-atomized sample, annealed at a temperature of $597^{\circ} \mathrm{C}$ and $656^{\circ} \mathrm{C}$, respectively. Analysis of the hysteresis loops allowed revealing values of coercivity, which were $13.9,12.7$ and $13.9 \mathrm{kA} / \mathrm{m}$ for the as-atomized sample, annealed at temperature $597^{\circ} \mathrm{C}$ and $656^{\circ} \mathrm{C}$, respectively.
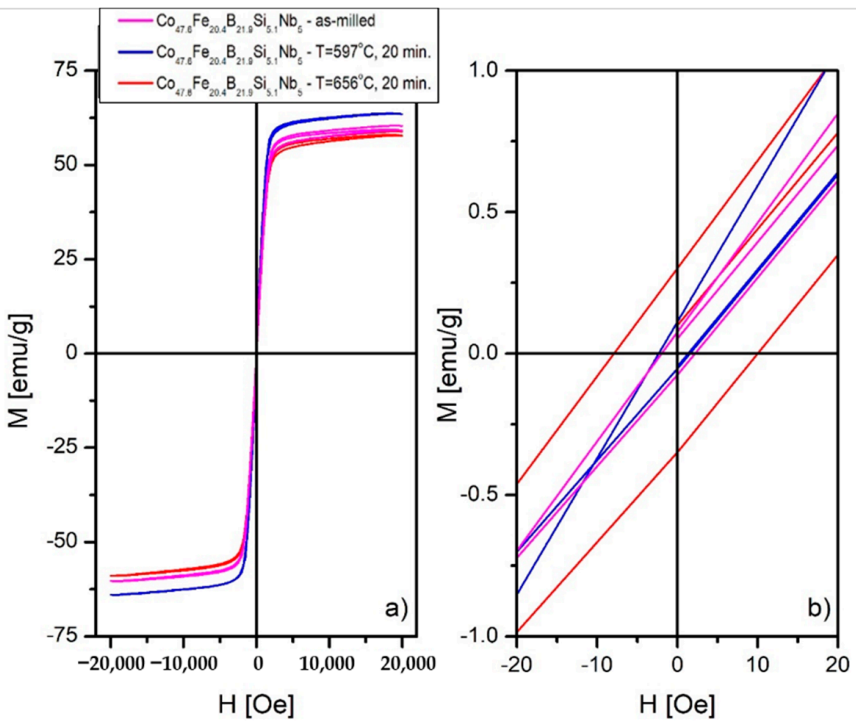

(A)

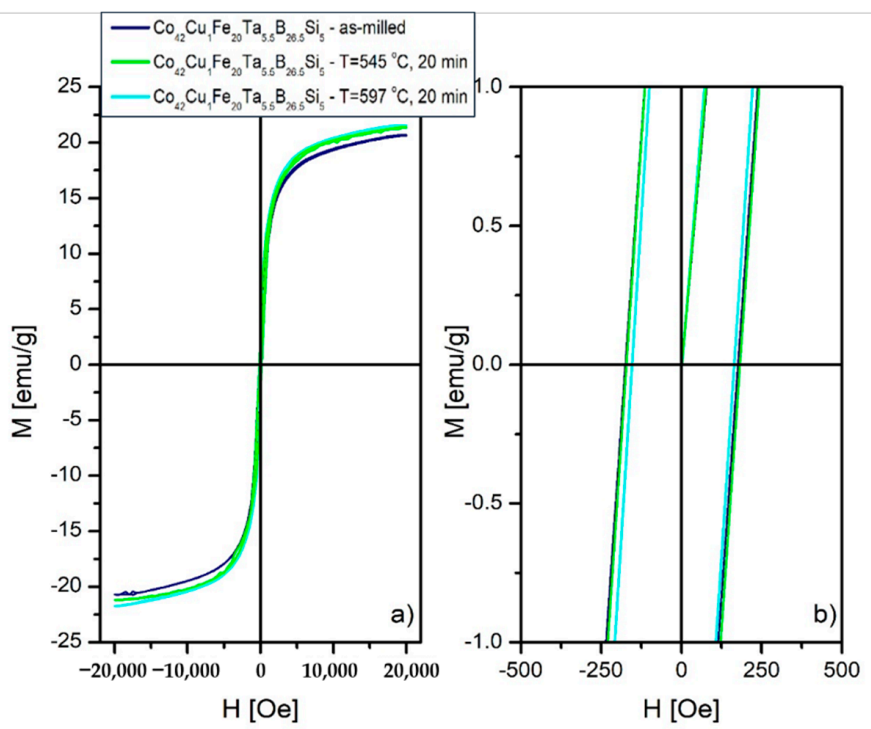

(B)

Figure 9. The room temperature hysteresis loops of the (A) $\mathrm{Co}_{47.6} \mathrm{~B}_{21.9} \mathrm{Fe}_{20.4} \mathrm{Si}_{5.1} \mathrm{Nb}_{5}$, (B) $\mathrm{Co}_{42} \mathrm{~B}_{26.5} \mathrm{Fe}_{20} \mathrm{Ta}_{5.5} \mathrm{Si}_{5} \mathrm{Cu}_{1}$ alloy; (as-atomized, and after heat treatment). 


\section{Discussion}

Based on the results shown in this work, atomization was confirmed as a suitable method to obtain powder-form alloys with high glass formation ability (GFA), including Co-based amorphous alloys such as $\mathrm{Co}_{47.6} \mathrm{~B}_{21.9} \mathrm{Fe}_{20.4} \mathrm{Si}_{5.1} \mathrm{Nb}_{5} \%$ at. and $\mathrm{Co}_{42} \mathrm{~B}_{26.5} \mathrm{Fe}_{20} \mathrm{Ta}_{5.5} \mathrm{Si}_{5} \mathrm{Cu}_{1} \%$ at. Other research also shows the proven accuracy of the method in developing regular spheric powder particles with the bell-shaped plot of the particle size distribution [44-46].

EDS analysis showed that the chemical composition of the first alloy, namely $\mathrm{Co}_{47.6}$ $\mathrm{Fe}_{20.4} \mathrm{~B}_{21.9} \mathrm{Si}_{5.1} \mathrm{Nb}_{5.0} \%$ at, was suitable to gain a homogeneous practice through the atomization process. All particles, from the fraction $20-50 \mu \mathrm{m}$ and $50-80 \mu \mathrm{m}$, had a steady level of concentration of each chemical composition. This was also confirmed by a microscopic observation shown in Figure 2b. However, the second alloy had less homogeneity. Some fluctuations of the concentration elements were observed, suggesting that the atomization process of $\mathrm{Co}_{42} \mathrm{Cu}_{1} \mathrm{Fe}_{20} \mathrm{Ta}_{5.5} \mathrm{~B}_{26.5} \mathrm{Si}_{5}$ should be improved. These results are in line with [47] which confirm the homogeneous chemical composition obtained by atomization as in the first alloy.

Differential thermal analysis for the first alloy in the form of powder, granulation 20-50 $\mu \mathrm{m}$, exhibited for the $\mathrm{T}_{\mathrm{g}}$ peak $620^{\circ} \mathrm{C}$ and the $\mathrm{T}_{\mathrm{x}}$ inflexion $663^{\circ} \mathrm{C}$. According to the work $[48,49]$ for the same chemical composition of the alloy as the first alloy, but in rod form, the $\mathrm{T}_{\mathrm{g}}$ peak is set at $580{ }^{\circ} \mathrm{C}$ and the inflection of $\mathrm{T}_{\mathrm{x}} 623$ or $635^{\circ} \mathrm{C}$ for $[48,49]$, respectively. Since the heat rate in the experiments in this work and in $[48,49]$ was the same $(40 \mathrm{~K} / \mathrm{min}$ ), it could be concluded that the form of the material tested causes translation to the right graph of DTA for about $40^{\circ} \mathrm{C}$.

For the second alloy in the form of powder 20-50 $\mu \mathrm{m}$, DTA in this work did not show a $T_{g}$ peak while according to [43] for the alloy identical to second but in rods $T_{g}$ set at $623^{\circ} \mathrm{C}$. The $\mathrm{T}_{\mathrm{x}}$ onset read from DTA in this work was set at $595^{\circ} \mathrm{C}$ and is $82{ }^{\circ} \mathrm{C}$ lower than the temperature measured in [43]. The difference between temperatures might be due to the different forms of the tested samples and the different heat rates. In [43] the heat rate was twice lower $(20 \mathrm{~K} / \mathrm{min})$ than in this work.

The results of the first and second XRD pattern confirm those of earlier studies, such as [43,50-52]. Where respectively, the first two works confirm that alloys with similar elements developed first a crystal phase ( $\mathrm{Co}, \mathrm{Fe}) 2 \mathrm{~B}$ and [50-52] shows a crystallization of $\alpha-(\mathrm{Co}, \mathrm{Fe})$ which was developed only in the second alloy after annealing. The first alloy after atomization was fully amorphous, while the second already had some crystal phase (in an as-atomized state). In the study literature, the first alloy has a $\Delta \mathrm{T}_{\mathrm{x}}=52$ or $44{ }^{\circ} \mathrm{C}[48,49]$, and the second $\Delta \mathrm{T}_{\mathrm{x}}=42{ }^{\circ} \mathrm{C}$ [43], which may suggest that the first alloy has a better glass-forming ability that can explain the different states of particles in the samples as atomized.

After annealing, the hardness of the powder particles increases-for annealing in $T_{x}$ by about $11 \%$ and for annealing in $\mathrm{T}_{x}$ for $26 \%$. The same as the elastic module, for $\mathrm{T}_{\mathrm{g}}$ annealing increased by $24 \%$ and for $\mathrm{T}_{\mathrm{x}}$ by $31 \%$. All of these increases are caused by increasing the amount of crystal phase in samples and correspond to the results of other researchers $[53,54]$. However, other research refers to Fe-based alloys because those based on Co have not been studied well enough. Increasing hardness is explained as the first state being a relaxation of the structure and the second as a growing crystal hard phase. In the research [54] there is also information on the short range of decreasing hardness that is the cause of initial crystallization without the possibilities of relaxation, but in this work that case did not appear. The same studies explain and confirm the increase of the elastic module through the annealing of amorphous samples.

The Mössbauer spectroscopy studies revealed traces of some phases, such as the paramagnetic disordered Fe-based phase and ferromagnetic $\mathrm{Fe}_{2} \mathrm{~B}$ and $\mathrm{Fe}-\mathrm{Nb}-\mathrm{B}$ phases for the $\mathrm{CO}_{47.6} \mathrm{~B}_{21.9} \mathrm{Fe}_{20.4} \mathrm{Si}_{5.1} \mathrm{Nb}_{5}$ alloy. The content of each phase was changed slightly during heat treatment. Similar behavior was detected in the $\mathrm{Co}_{42} \mathrm{~B}_{26.5} \mathrm{Fe}_{20} \mathrm{Ta}_{5.5} \mathrm{Si}_{5} \mathrm{Cu}_{1}$ alloy samples. The spectra contain traces of the paramagnetic $\mathrm{Fe}-\mathrm{Cu}$ phase and the ferromagnetic $\mathrm{Fe}_{2} \mathrm{~B}$ and $\mathrm{Fe}-\mathrm{Nb}-\mathrm{B}$ phases. Magnetic studies revealed that in the case of the 
$\mathrm{Co}_{47.6} \mathrm{~B}_{21.9} \mathrm{Fe}_{20.4} \mathrm{Si}_{5.1} \mathrm{Nb}_{5}$ alloy, it is a soft magnetic material both: in the as-atomized state and after heat treatment. $\mathrm{Co}_{47.6} \mathrm{Fe}_{20.4} \mathrm{~B}_{21.9} \mathrm{Si}_{5.1} \mathrm{Nb}_{5}$ alloy establishes the saturation magnetization $59.4,63.6$ and $58.1 \mathrm{Am}^{2} / \mathrm{kg}$ for as-atomized, annealed at $T_{g}$ and $T_{x}$, respectively. Taking into account the results provided by Ackland et al. [28] the measured values are almost twice lower. It is probably caused by the degradation of a structure during atomization. In the case of saturation magnetization, no strong deviations were observed, which suggests that the material is structurally stable in the as-atomization state and after annealing. Results for the coercivity equalled 319, 321 and $690 \mathrm{~A} / \mathrm{m}$, respectively, for the same states as above. The results correspond well to the data provided by other authors [28,55-58].

Significantly different properties were measured for samples of the $\mathrm{Co}_{42} \mathrm{Cu}_{1} \mathrm{Fe}_{20} \mathrm{Ta}_{5.5}$ $\mathrm{B}_{26.5} \mathrm{Si}_{5}$ alloy. The saturation magnetization was almost three times lower than for the first alloy, namely 20.6, 21.4 and $21.6 \mathrm{Am}^{2} / \mathrm{kg}$ for the as-atomized sample, annealed at $\mathrm{T}_{\mathrm{g}}$ and $\mathrm{T}_{\mathrm{x}}$, respectively. Compared to the data provided by Ackland et al. [28] and Mohapatra et al. [58] our results are lower or comparable, which is induced by a lower Fe content and other preparation conditions. Coercivity for the second alloy was even 10 times lower than for a first alloy $13.9,12.7$ and $13.9 \mathrm{kA} / \mathrm{m}$ for the as-atomized sample, annealed at $\mathrm{T}_{\mathrm{g}}$ and $\mathrm{T}_{\mathrm{x}}$, respectively. Such values qualify the produced samples as semi-hard magnetic materials. Moreover, similar to the first alloy, the fluctuations of saturation magnetization were not observed. As is visible in Figure 9a, the $\mathrm{Nb}$-doped samples have an almost rectangular shape of hysteresis loops. The rectangular shape of hysteresis loops is typical for axial anisotropy. Most likely, some axial anisotropy is induced by $\mathrm{Nb}$ atoms. In the case of samples doped by Ta, the inclination of hysteresis loops is visible in Figure 9b, which means that $\mathrm{Ta}$ atoms do not induce an axial anisotropy compared to $\mathrm{Nb}$ atoms. In the case of Ta-doped samples, we can talk about circumferential anisotropy. A similar effect was observed in Co-based microwires induced by thermal treatment $[59,60]$.

\section{Conclusions}

- $\mathrm{Co}_{47.6} \mathrm{~B}_{21.9} \mathrm{Fe}_{20.4} \mathrm{Si}_{5.1} \mathrm{Nb}_{5} \%$ at. and $\mathrm{Co}_{42} \mathrm{~B}_{26.5} \mathrm{Fe}_{20} \mathrm{Ta}_{5.5} \mathrm{Si}_{5} \mathrm{Cu}_{1} \%$ at. are suitable alloys to produce powder by atomization and the obtained particles have a chemical homogeneity concentration. However, the second alloy had a slightly smaller homogeneity than the first alloy.

- The atomized powder $50-80 \mu \mathrm{m}$ of $\mathrm{Co}_{47.6} \mathrm{Fe}_{20.4} \mathrm{~B}_{21.9} \mathrm{Si}_{5.1} \mathrm{Nb}_{5}$ alloy exhibits a $\mathrm{T}_{\mathrm{g}}=620^{\circ} \mathrm{C}$ and $\mathrm{T}_{\mathrm{x}}=663{ }^{\circ} \mathrm{C}$ on a DTA research. $\mathrm{Co}_{42} \mathrm{Cu}_{1} \mathrm{Fe}_{20} \mathrm{Ta}_{5.5} \mathrm{~B}_{26.5} \mathrm{Si}_{5}$ exhibits the smaller $\mathrm{T}_{\mathrm{x}}$ (then first alloy), namely $595^{\circ} \mathrm{C}$ and does not show any $\mathrm{T}_{\mathrm{g}}$ sights. Those temperatures are lower than the temperature taken from the literature, which can be caused by a different form of tested samples (powders vs. rods).

- The surface of the first and second alloy did not visibly change after annealing at $T_{g}$ nor $\mathrm{T}_{\mathrm{x}}$.

- The annealing for $20 \mathrm{~min}$ at $\mathrm{T}_{\mathrm{g}}$ and the annealing at the $\mathrm{T}_{\mathrm{x}}$ powder samples of $\mathrm{Co}_{47.6} \mathrm{~B}_{21.9} \mathrm{Fe}_{20.4} \mathrm{Si}_{5.1} \mathrm{Nb}_{5}$ and $\mathrm{Co}_{42} \mathrm{~B}_{26.5} \mathrm{Fe}_{20} \mathrm{Ta}_{5.5} \mathrm{Si}_{5} \mathrm{Cu}_{1}$ causes an increase of the hardness of the indentation and increase of the elastic indentation module.

- Magnetic research shows that the $\mathrm{Co}_{47.6} \mathrm{~B}_{21.9} \mathrm{Fe}_{20.4} \mathrm{Si}_{5.1} \mathrm{Nb}_{5}$ alloy is a soft magnetic material, both in the atomized state and after annealing state. $\mathrm{Co}_{42} \mathrm{~B}_{26.5} \mathrm{Fe}_{20} \mathrm{Ta}_{5.5} \mathrm{Si}_{5} \mathrm{Cu}_{1}$ shows semi-hard magnetic material properties in both states.

Author Contributions: Conceptualization, A.K., W.P. and A.M.; validation, A.K., W.P. and A.M.; formal analysis, A.K., W.P. and A.M.; investigation, A.K.; writing—original draft preparation, A.K. and P.G.; writing-review and editing, A.K., W.P. and A.M.; supervision, A.A.; funding acquisition, A.A., W.P. and P.G. All authors have read and agreed to the published version of the manuscript.

Funding: This research received no external funding.

Institutional Review Board Statement: Not applicable.

Informed Consent Statement: Not applicable. 
Data Availability Statement: Data is contained within the article.

Conflicts of Interest: The authors declare no conflict of interest.

\section{References}

1. Pilarczyk, W. Struktura i Właściwości Masywnych Szkieł Metalicznych w Stanie Po Wytworzeniu i Po Procesie Spawania Laserowego; Wydawnictwo Politechniki Śląskiej: Gliwice, Poland, 2017.

2. Stoica, M. Fe-Based Bulk Metallic Glasses: Understanding the Influence of Impurities on Glass Formation; Springer: Berlin/Heidelberg, Germany, 2017; ISBN 978-3-658-17018-9.

3. Żrodowski, Ł.; Wróblewski, R.; Choma, T.; Morończyk, B.; Ostrysz, M.; Leonowicz, M.; Łacisz, W.; Błyskun, P.; Wróbel, J.S.; Cieślak, G.; et al. Novel Cold Crucible Ultrasonic Atomization Powder Production Method for 3D Printing. Materials 2021, 14, 2541. [CrossRef] [PubMed]

4. Liu, X.; Bi, J.; Meng, Z.; Li, R.; Li, Y.; Zhang, T. Tribological Behaviors of High-Hardness Co-Based Amorphous Coatings Fabricated by Laser Cladding. Tribol. Int. 2021, 162, 107142. [CrossRef]

5. Lin, T.-J.; Sheu, H.-H.; Lee, C.-Y.; Lee, H.-B. The Study of Mechanical Properties and Corrosion Behavior of the Fe-Based Amorphous Alloy Coatings Using High Velocity Oxygen Fuel Spraying. J. Alloy Compd. 2021, 867, 159132. [CrossRef]

6. Ciftci, N.; Yodoshi, N.; Armstrong, S.; Mädler, L.; Uhlenwinkel, V. Processing Soft Ferromagnetic Metallic Glasses: On Novel Cooling Strategies in Gas Atomization, Hydrogen Enhancement, and Consolidation. J. Mater. Sci. Technol. 2020, 59, 26-36. [CrossRef]

7. Zhao, Y.F.; Si, J.J.; Song, J.G.; Yang, Q.; Hui, X.D. Synthesis of Mg-Zn-Ca Metallic Glasses by Gas-Atomization and Their Excellent Capability in Degrading Azo Dyes. Mater. Sci. Eng. B 2014, 181, 46-55. [CrossRef]

8. Shi, Y.; Lu, W.; Sun, W.; Zhang, S.; Yang, B.; Wang, J. Impact of Gas Pressure on Particle Feature in Fe-Based Amorphous Alloy Powders via Gas Atomization: Simulation and Experiment. J. Mater. Sci. Technol. 2022, 105, 203-213. [CrossRef]

9. Katz-Demyanetz, A.; Koptyug, A.; Popov, V.V. In-Situ Alloying as a Novel Methodology in Additive Manufacturing. In Proceedings of the 2020 IEEE 10th International Conference on Nanomaterials: Applications Properties (NAP), Sumy, Ukraine, 9-13 November 2020; pp. 02SAMA05-1-02SAMA05-4.

10. Deng, L.; Wang, S.; Wang, P.; Kühn, U.; Pauly, S. Selective Laser Melting of a Ti-Based Bulk Metallic Glass. Mater. Lett. 2018, 212, 346-349. [CrossRef]

11. Nong, X.D.; Zhou, X.L.; Ren, Y.X. Fabrication and Characterization of Fe-Based Metallic Glasses by Selective Laser Melting. Opt. Laser Technol. 2019, 109, 20-26. [CrossRef]

12. Popov, V.V.; Grilli, M.L.; Koptyug, A.; Jaworska, L.; Katz-Demyanetz, A.; Klobčar, D.; Balos, S.; Postolnyi, B.O.; Goel, S. Powder Bed Fusion Additive Manufacturing Using Critical Raw Materials: A Review. Materials 2021, 14, 909. [CrossRef] [PubMed]

13. Ding, P.; Mao, A.; Zhang, X.; Jin, X.; Wang, B.; Liu, M.; Gu, X. Preparation, Characterization and Properties of Multicomponent AlCoCrFeNi ${ }_{2.1}$ Powder by Gas Atomization Method. J. Alloy Compd. 2017, 721, 609-614. [CrossRef]

14. Yang, T.; Cai, B.; Shi, Y.; Wang, M.; Zhang, G. Preparation of Nanostructured CoCrFeMnNi High Entropy Alloy by Hot Pressing Sintering Gas Atomized Powders. Micron 2021, 147, 103082. [CrossRef]

15. Han, C.; Fang, Q.; Shi, Y.; Tor, S.B.; Chua, C.K.; Zhou, K. Recent Advances on High-Entropy Alloys for 3D Printing. Adv. Mater. 2020, 32, 1903855. [CrossRef] [PubMed]

16. Sumita, M.; Hanawa, T.; Ohnishi, I.; Yoneyama, T. 9.04-Failure Processes in Biometallic Materials. In Comprehensive Structural Integrity; Milne, I., Ritchie, R.O., Karihaloo, B., Eds.; Pergamon: Oxford, UK, 2003; pp. 131-167, ISBN 978-0-08-043749-1.

17. Klement, W.; Willens, R.H.; Duwez, P. Non-Crystalline Structure in Solidified Gold-Silicon Alloys. Nature 1960, 187, 869-870. [CrossRef]

18. Msetra, Z.; Khitouni, N.; Suñol, J.J.; Khitouni, M.; Chemingui, M. Characterization and Thermal Analysis of New Amorphous $\mathrm{Co}_{60} \mathrm{Fe}_{18} \mathrm{Ta}_{8} \mathrm{~B}_{14}$ alloy Produced by Mechanical Alloying. Mater. Lett. 2021, 292, 129532. [CrossRef]

19. Liu, C.; Li, Q.; Huo, J.; Yang, W.; Chang, L.; Chang, C.; Sun, Y. Near Room-Temperature Magnetocaloric Effect of Co-Based Bulk Metallic Glass. J. Magn. Magn. Mater. 2018, 446, 162-165. [CrossRef]

20. Wang, Q.; Zhou, J.; Zeng, Q.; Zhang, G.; Yin, K.; Liang, T.; Yang, W.; Stoica, M.; Sun, L.; Shen, B. Ductile Co-Based Bulk Metallic Glass with Superhigh Strength and Excellent Soft Magnetic Properties Induced by Modulation of Structural Heterogeneity. Materialia 2020, 9, 100561. [CrossRef]

21. Kim, J.T.; Hong, S.H.; Kim, Y.S.; Park, H.J.; Maity, T.; Chawake, N.M.; Prashanth, K.G.; Park, J.M.; Song, K.K.; Wang, W.M.; et al. Co-Cr-Mo-C-B Metallic Glasses with Wide Supercooled Liquid Region Obtained by Systematic Adjustment of the Metalloid Ratio. J. Non-Cryst. Solids 2019, 505, 310-319. [CrossRef]

22. Dastani, M.M.; AL-Ali, M.H.; Moradi, M. Influence of Current Annealing on the Magneto-Impedance Response of Co-Based Ribbons Arising from Surface Structural Improvement. J. Non-Cryst. Solids 2019, 516, 9-13. [CrossRef]

23. Zhao, C.; Pan, L.; Li, X.; Ma, L.; Liu, Q.; Wang, J. Optimization of Magnetoimpedance Effect in Co-Based Ribbon by Laser Patterning for Sensor Arrays Application. J. Phys. D Appl. Phys. 2018, 51, 045005. [CrossRef]

24. Liang, X.; Li, Y.; Bao, F.; Zhu, Z.; Zhang, H.; Zhang, W. Roles of Y and Fe Contents on Glass-Forming Ability, Thermal Stability, and Magnetic Properties of Co-Based Co-Fe-Y-B Bulk Metallic Glasses. Intermetallics 2021, 132, 107135. [CrossRef]

25. Zhang, G.; Zhang, H.; Yue, S.; Cheng, R.; Wang, A.; He, A.; Dong, Y.; Ni, H.; Liu, C.-T. Preparation of Non-Magnetic and Ductile Co-Based Bulk Metallic Glasses with High GFA and Hardness. Intermetallics 2019, 107, 47-52. [CrossRef] 
26. Murray, C.; Sun, S.; Gaschler, W.; Doyle, H.; Betley, T.; Kagan, C. Colloidal Synthesis of Nanocrystals and Nanocrystal Superlattices. IBM J. Res. Dev. 2001, 45, 47-56. [CrossRef]

27. Yang, H.T.; Su, Y.K.; Shen, C.M.; Yang, T.Z.; Gao, H.J. Synthesis and Magnetic Properties of $\varepsilon$-Cobalt Nanoparticles. Surf. Interface Anal. 2004, 36, 155-160. [CrossRef]

28. Ackland, K.; Masood, A.; Kulkarni, S.; Stamenov, P. Ultra-Soft Magnetic Co-Fe-B-Si-Nb Amorphous Alloys for High Frequency Power Applications. AIP Adv. 2018, 8, 056129. [CrossRef]

29. Pinzón-Escobar, E.; Montiel, H.; García, A.; Alvarez, G. Magnetic and Electrical Properties of Vitrovac/Au/Vitrovac Multilayered Obtained by Means of Magnetron Sputtering. J. Phys. Conf. Ser. 2021, 1723, 012025. [CrossRef]

30. Kekalo, I.; Stolyarov, V.; Taranichev, V. The Effect of Annealing on the Laws of Magnetization and Magnetization Reversal in Amorphous Alloys; Amorphous Metal Alloys, Metallurgy: Moscow, Russia, 1983.

31. Nosenko, A.V.; Kyrylchuk, V.V.; Semen'ko, M.P.; Nowicki, M.; Marusenkov, A.; Mika, T.M.; Semyrga, O.M.; Zelinska, G.M.; Nosenko, V.K. Soft Magnetic Cobalt Based Amorphous Alloys with Low Saturation Induction. J. Magn. Magn. Mater. 2020, 515, 167328. [CrossRef]

32. Rezaei-Shahreza, P.; Seifoddini, A.; Hasani, S. Microstructural and Phase Evolutions: Their Dependent Mechanical and Magnetic Properties in a Fe-Based Amorphous Alloy during Annealing Process. J. Alloy Compd. 2018, 738, 197-205. [CrossRef]

33. Hasani, S.; Rezaei-Shahreza, P.; Seifoddini, A. Effect of Cu Presence on Evolution of Mechanical and Magnetic Properties in a Novel Fe-Based Bulk Metallic Glass during Partial Annealing Process. Met. Mater. Trans. A 2019, 50, 63-71. [CrossRef]

34. Wang, Q.; Chen, M.; Shao, L.; Ge, Y.; Lin, P.; Chu, C.; Shen, B. Effects of Structural Relaxation on the Dye Degradation Ability of FePC Amorphous Alloys. J. Non-Cryst. Solids 2019, 525, 119671. [CrossRef]

35. Wang, Q.-Y.; Xi, Y.-C.; Zhao, Y.-H.; Liu, S.; Bai, S.-L.; Liu, Z.-D. Effects of Laser Re-Melting and Annealing on Microstructure, Mechanical Property and Corrosion Resistance of Fe-Based Amorphous/Crystalline Composite Coating. Mater. Charact. 2017, 127, 239-247. [CrossRef]

36. Xie, C.; Yang, Y.; Zhong, S.; Li, S.; Deng, S. Formation, Magnetic Properties and Bending Deformation of Fe-Based Amorphous Alloy without Metalloids. J. Alloy Compd. 2017, 695, 877-880. [CrossRef]

37. Onodera, R.; Kimura, S.; Watanabe, K.; Yokoyama, Y.; Makino, A.; Koyama, K. Nucleation Control for Fine Nano Crystallization of Fe-Based Amorphous Alloy by High-Magnetic-Field Annealing. J. Alloy Compd. 2015, 637, 213-218. [CrossRef]

38. Oliver, W.C.; Pharr, G.M. An Improved Technique for Determining Hardness and Elastic Modulus Using Load and Displacement Sensing Indentation Experiments. J. Mater. Res. 1992, 7, 1564-1583. [CrossRef]

39. Sneddon, I.N. The Relation between Load and Penetration in the Axisymmetric Boussinesq Problem for a Punch of Arbitrary Profile. Int. J. Eng. Sci. 1965, 3, 47-57. [CrossRef]

40. Zhang, T.; Yang, Q.; Ji, Y.; Li, R.; Pang, S.; Wang, J.; Xu, T. Centimeter-Scale-Diameter Co-Based Bulk Metallic Glasses with Fracture Strength Exceeding $5000 \mathrm{MPa}$. Chin. Sci. Bull. 2011, 56, 3972-3977. [CrossRef]

41. Wang, J.; Wang, L.; Guan, S.; Zhu, S.; Li, R.; Zhang, T. Effects of Boron Content on the Glass-Forming Ability and Mechanical Properties of Co-B-Ta Glassy Alloys. J. Alloy Compd. 2014, 617, 7-11. [CrossRef]

42. Lai, L.; He, R.; Ding, K.; Liu, T.; Liu, R.; Chen, Y.; Guo, S. Ternary Co-Mo-B Bulk Metallic Glasses with Ultrahigh Strength and Good Ductility. J. Non-Cryst. Solids 2019, 524, 119657. [CrossRef]

43. Yazici, Z.; Hitit, A.; Yalcin, Y.; Ozgul, M. Effects of Minor Cu and Si Additions on Glass Forming Ability and Mechanical Properties of Co-Fe-Ta-B Bulk Metallic Glass. Met. Mater. Int. 2016, 22, 50-57. [CrossRef]

44. Dai, T.; Wang, N. Study on Magnetic Properties and Degradability of Gas Atomization Fe-Based (Fe-Si-B-P) Amorphous Powder. J. Supercond. Nov. Magn. 2019, 32, 3699-3702. [CrossRef]

45. Alvarez, K.L.; Manuel Martin, J.; Ipatov, M.; Dominguez, L.; Gonzalez, J. Magnetic Properties of Annealed Amorphous $\mathrm{Fe}_{72.5} \mathrm{Si}_{12.5} \mathrm{~B}_{15}$ Alloy Obtained by Gas Atomization Technique. IEEE Trans. Magn. 2018, 54, 2002405. [CrossRef]

46. Ciftci, N.; Ellendt, N.; von Bargen, R.; Henein, H.; Maedler, L.; Uhlenwinkel, V. Atomization and Characterization of a Glass Forming Alloy $\left\{\left(\mathrm{Fe}_{0.6} \mathrm{Co}_{0.4}\right)_{0.75} \mathrm{~B}_{0.2} \mathrm{Si}_{0.05}\right\}_{96} \mathrm{Nb}_{4}$. J. Non-Cryst. Solids 2014, 394, 36-42. [CrossRef]

47. Miura, A.; Dong, W.; Fukue, M.; Yodoshi, N.; Takagi, K.; Kawasaki, A. Preparation of Fe-Based Monodisperse Spherical Particles with Fully Glassy Phase. J. Alloy Compd. 2011, 509, 5581-5586. [CrossRef]

48. Zhang, G.; Wang, Q.; Yuan, C.; Yang, W.; Zhou, J.; Xue, L.; Hu, F.; Sun, B.; Shen, B. Effects of Cu Additions on Mechanical and Soft-Magnetic Properties of CoFeBSiNb Bulk Metallic Glasses. J. Alloy Compd. 2018, 737, 815-820. [CrossRef]

49. Dong, Y.; Wang, A.; Man, Q.; Shen, B. $\left(\mathrm{Co}_{1-\mathrm{x}} \mathrm{Fe}_{\mathrm{x}}\right)_{68} \mathrm{~B}_{21.9} \mathrm{Si}_{5.1} \mathrm{Nb}_{5}$ Bulk Glassy Alloys with High Glass-Forming Ability, Excellent Soft-Magnetic Properties and Superhigh Fracture Strength. Intermetallics 2012, 23, 63-67. [CrossRef]

50. Li, L.; Sun, H.; Fang, Y.; Zheng, J. Co-Based Soft Magnetic Bulk Glassy Alloys Optimized for Glass-Forming Ability and Plasticity. Bull. Mater. Sci. 2016, 39, 691-695. [CrossRef]

51. Shen, B.; Chang, C.; Kubota, T.; Inoue, A. Superhigh Strength and Excellent Soft-Magnetic Properties of $\left[\left(\mathrm{Co}_{1-\mathrm{x}} \mathrm{Fex}_{0.75} \mathrm{~B}_{0.2} \mathrm{Si}_{0.05}\right]_{96}\right.$ $\mathrm{Nb}_{4}$ Bulk Glassy Alloys. J. Appl. Phys. 2006, 100, 013515. [CrossRef]

52. Shen, B.; Inoue, A. (Fe,Co,Ni)-B-Si-Nb Bulk Glassy Alloy With Super-High Strength and Some Ductility [Article Retracted]. J. Mater. Res. 2005, 20, 1-5. [CrossRef]

53. Pang, L.L.; Inoue, A.; Zanaeva, E.N.; Wang, F.; Bazlov, A.I.; Han, Y.; Kong, F.L.; Zhu, S.L.; Shull, R.B. Nanocrystallization, Good Soft Magnetic Properties and Ultrahigh Mechanical Strength for $\mathrm{Fe}_{82-85} \mathrm{~B}_{13-16} \mathrm{Si}_{1} \mathrm{Cu}_{1}$ Amorphous Alloys. J. Alloy Compd. 2019, 785, 25-37. [CrossRef] 
54. Han, J.; Wang, C.; Kou, S.; Liu, X. Thermal Stability, Crystallization Behavior, Vickers Hardness and Magnetic Properties of Fe-Co-Ni-Cr-Mo-C-B-Y Bulk Metallic Glasses. Trans. Nonferrous Met. Soc. China 2013, 23, 148-155. [CrossRef]

55. Błoch, K.; Nabiałek, M.; Postawa, P.; Sandu, A.V.; Śliwa, A.; Jeż, B. The Magnetisation Process of Bulk Amorphous Alloys: $\mathrm{Fe}_{36+\mathrm{x}} \mathrm{Co}_{36-\mathrm{x}} \mathrm{Y}_{8} \mathrm{~B}_{20}$, Where: $\mathrm{X}=0,3,7$, or 12. Materials 2020, 13, 846. [CrossRef] [PubMed]

56. Nabiałek, M.; Jeż, B.; Pietrusiewicz, P.; Jeż, K.; Płoszaj, B.; Sandu, A.V.; Abdullah, M.M.A.B.; Wysłocki, J.; Kalwik, A.; Postawa, P.; et al. Effect of Chemical Composition on Curie Temperature of FeCoB Alloys. Acta Phys. Pol. A 2021, 139, 491-494. [CrossRef]

57. Olekšáková, D.; Kollár, P.; Füzer, J.; Onderko, F.; Dobák, S.; Viňáš, J.; Fáberová, M.; Bureš, R. Magnetic Properties of Sintered Fe_\{50\}Co_\{50\} Powder Cores. Acta Phys. Pol. A 2017, 131, 807-809. [CrossRef]

58. Mohapatra, J.; Xing, M.; Elkins, J.; Liu, J.P. Hard and Semi-Hard Magnetic Materials Based on Cobalt and Cobalt Alloys. J. Alloy Compd. 2020, 824, 153874. [CrossRef]

59. Nematov, M.G.; Baraban, I.; Yudanov, N.A.; Rodionova, V.; Qin, F.X.; Peng, H.-X.; Panina, L.V. Evolution of the Magnetic Anisotropy and Magnetostriction in Co-Based Amorphous Alloys Microwires Due to Current Annealing and Stress-Sensory Applications. J. Alloy Compd. 2020, 837, 155584. [CrossRef]

60. Zhukov, A.; Talaat, A.; Ipatov, M.; Blanco, J.M.; Zhukova, V. Tailoring of Magnetic Properties and GMI Effect of Co-Rich Amorphous Microwires by Heat Treatment. J. Alloy Compd. 2014, 615, 610-615. [CrossRef] 